\title{
A Finite Element Model of the Human Head for Simulation of Bone-conducted Sound
}

\author{
You Chang
}

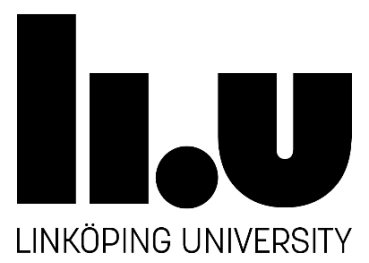

Department of Clinical and Experimental Medicine

Linköping University, Sweden

Linköping 2018 
Titel

A finite element model of the human head for simulation of bone conducted sound

(C)You Chang, 2018

Cover/picture/Illustration/Design: You Chang \& Yicheng Wang

Published article has been reprinted with the permission of the copyright holder.

Printed in Sweden by LiU-Tryck, Linköping, Sweden, 2018

ISBN 978-91-7685-310-8

ISSN 0345-0082 


\section{POPULÄRVETENSKAPLIG SAMMANFATTNING}

Hörselproblem är allmänt utbredd bland befolkningen men drabbar primärt äldre. Problem med hörseln räknas idag som det 3:e största folkhälsoproblemet i västvärlden. Den vanligaste rehabiliteringen för personer med hörselproblem är hörapparater. Dessa apparater förstärker och leder ljudet till hörselorganet på ett så optimalt sätt som möjligt för personen med hörselnedsättningen. Beroende på orsaken till hörselproblemet används olika typer av hörhjälpmedel. Ett sådant hörhjälpmedel är benledningshörapparater där ljudet omvandlas till vibrationer som leds via skallen till innerörat och uppfattas som ljud.

Ett viktigt verktyg för att förstå hörselfunktioner och det som händer vid skadad hörselfunktion, samt utveckla nya och bättre hörapparater, är modeller av hörseln. Hittills har det saknats en modell för benledningshörsel som på ett korrekt sätt kan beskriva de dynamiska funktionerna hos människan.

Syftet med detta projekt var att utveckla en sådan modell. Modellen bygger på finita element metoden, där de geometriska strukturerna delas upp i små pyramidliknande strukturer där ekvationerna för vibrationsöverföring löses i varje liten del och sedan slås ihop för att beskriva vibrationerna i hela strukturen. I detta fall modellerades huvudet hos en kvinna och de ingående anatomiska strukturerna delades upp i åtta olika delar: 1) mjukvävnad, 2) hård benvävnad, 3) mjuk benvävnad, 4) vätska runt hjärnan (cerebrospinalvätska), 5) hjärnvävnad, 6) brosk, 7) ögon och 8) inneröron. Parametrarna till modellen anpassades till dokumenterade värden och simuleringar gjorda med modellen liknade experimentella mätningar gjorda på huvuden tidigare.

Modellen kunde sen användas för att undersöka hur benledningsvibrationer transmitteras i huvudet. Simuleringarna visade att det är framförallt i skallbenet som vibrationer fortplantar sig även om det finns signifikant vibrationsenergi i mjukdelarna för lägre frekvenser. Simuleringarna visade även at det var framförallt i skallbasen som ljudvibrationerna fortplantade sig och till väldigt liten del över kraniet. I en ytterligare studie utvärderades de befintliga typerna av benledningshörapparater. Denna utvärdering är unik då alla typer inte tidigare har kunnat utvärderas mot varandra. Utvärderingen visar att det är relativt liten skillnad på de olika apparattyperna för lägre frekvenser, men för högre frekvenser är de typer som på något sätt kopplar vibratorn direkt till skallbenet överlägsna de typer som appliceras mot huden. Speciellt dåligt fungerade den typ av apparat som klistrades fast mot huden. 

"Keep performing good deeds, without asking for reward, will the God bless YOU." “但行好事, 莫问前程。” 《The wisdom of ancient aphorisms》 



\section{CONTENTS}

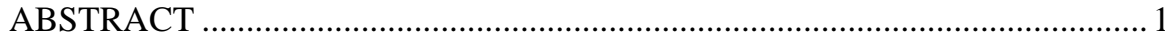

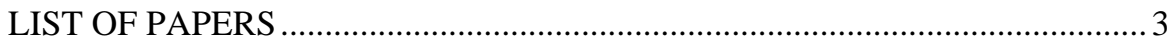

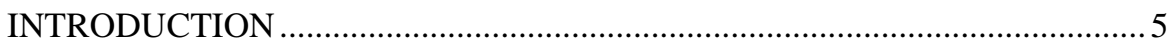

Background of bone-conducted sound ...................................................... 5

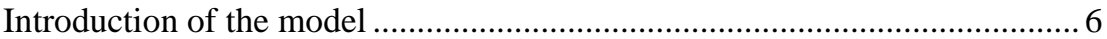

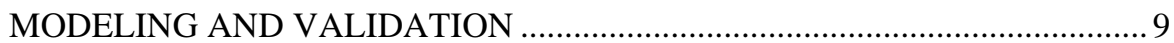

The first model: Dry skull model (Paper I).................................................... 9

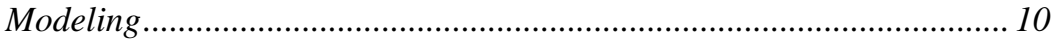

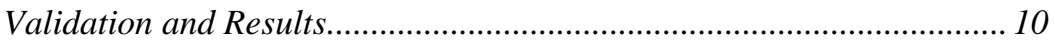

The second model: Whole head model (LiUHead) (Paper II)....................... 12

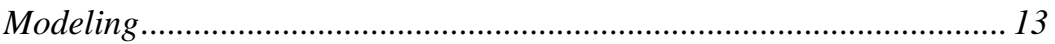

Validation and Results...................................................................... 15

INVESTIGATIONS USING THE LIUHEAD ................................................. 19

Power distribution and transmission (Paper III) .......................................... 19

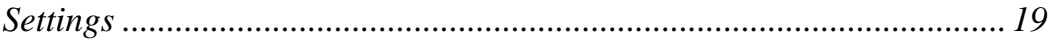

Results and conclusion ......................................................................... 21

Characteristics of Bone-conduction Devices (Paper IV) ............................... 23

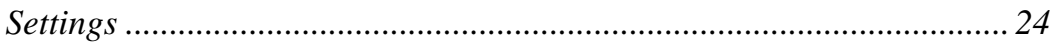

Results and conclusion ........................................................................ 25

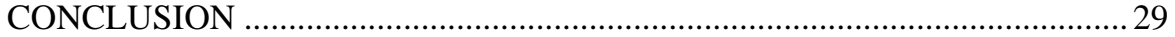

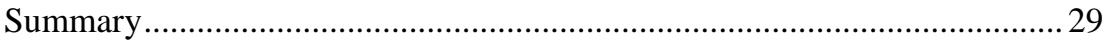

Future Research ..................................................................................... 30

Effect of the skin/soft tissue thickness and transducer attachments area 30

Transcranial attenuation and time delay ................................................ 31

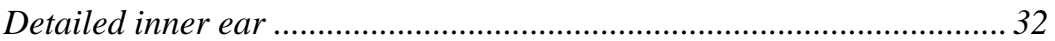

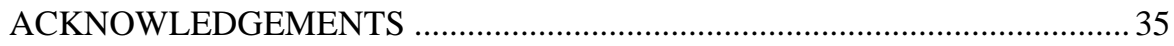

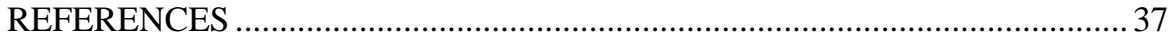





\section{ABSTRACT}

Bone conduction (BC) is usually understood as the hearing sensation based on the vibrations of the skull bone and surrounding tissues. The fact that vibration of the skull bones can result in a sound percept has been known for a long time. However, it is difficult to give a general definition of BC sound. Normally, BC sound is described as the sound energy transmitted through the body (comprising the solid and fluid parts) then the outer, middle and inner ear are involved and finally produce a perception of sound.

Even if $\mathrm{BC}$ sound perception has been studied for more than a century, the whole pattern of BC sound transmission is still not complete. There are limitations for experimental investigation of $\mathrm{BC}$ sound, such as the complexity of experimental manipulations and individual differences between subjects resulting in difficult to interpret outcomes. One way to overcome some of those issues is the use of a simulation model for BC sound. However, until now, the published models are unable to provide a holistic response of $\mathrm{BC}$ sound in the human. Therefore, the primary aim of this thesis is to develop a finite element (FE) model that could simulate BC sound transmission in the human. Based on cryosectional images of a female, the LiUHead was developed as a FE model of the human head with the structure and material properties of real human. Most the structures and tissues which could contribute to the BC transmission were included in the LiUHead. The simulation results of the LiUHead agreed with experimental data obtained in both cadaver heads and live humans.

After the development and validation of the LiUHead, the model was used to investigate BC sound. Since BC sound is transmitted in and between the tissues, the power transmission of BC sound was investigated in the LiUHead in the frequency domain. When the stimulation was applied on the surface of the skull at the mastoid position, the results of the simulations show that, as the name suggest, the skull bone dominants the $\mathrm{BC}$ sound transmission. The soft tissues and cartilages are as the second most important media of the $\mathrm{BC}$ sound while the skull interior is the least important for the $\mathrm{BC}$ transmission. Moreover, according to the power flux in the skull, the $\mathrm{BC}$ vibrations are mainly concentrated at the skull base. Other important transmission pathways are located at the occipital bone at the posterior side of the head, but the power transmitted over the face, forehead and vertex is minor. There is power interaction between the skull bone and skull interior near the stimulation position but the transmission of sound power through the brain seem to be minimal. Since the power or energy is difficult to measure in an experimental setting, this investigation gave unique knowledge about $\mathrm{BC}$ sound transmission in the head and the interaction between the tissues. 
As a common application for BC sound, bone-conduction devices (BCDs) are used to stimulate the hearing and is a method for hearing loss rehabilitation. Nowadays many different kinds of BCDs are available. However, most studies failed to compare the different types of BCDs in the same conditions as well as between several BCDs as it is not possible to compare several BCDs within the same subject due to the implantation required for several BCDs. The model gives a unique opportunity to evaluate various BCDs in the same head. Eight different BCDs, including four kinds of skin-drive $\mathrm{BCDs}$, three kinds of direct-drive $\mathrm{BCDs}$, and one in-themouth device, were applied to the LiUHead and the simulation results were evaluated. The results proved that the direct-drive BCDs and the in-the-mouth device gave similar vibration responses at the cochlea. At low frequencies, the skin-drive $\mathrm{BCDs}$ had similar or even better cochlear responses than the direct-drive BCDs. However, the direct-drive $\mathrm{BCDs}$ gave stable responses at mid-frequencies and gave higher responses than the skin-drive BCDs at high frequencies. These results are beneficial evaluating and for designing and improving current BCDs.

The ultimate goal of this thesis is to provide a computational model for BC sound that can be used for evaluation of BC sound transmission. This was accomplished by the LiUHead that gave results comparable to experimental data and enabled investigations that cannot easily be conducted in experiments. 


\section{LIST OF PAPERS}

Paper I. Namkeun Kim, You Chang, and Stefan Stenfelt (2014). "A three-dimensional finite-element model of a human dry skull for bone-conduction hearing." BioMed research international, vol. 2014, Article ID 519429, 9 pages.

Paper II. You Chang, Namkeun Kim, and Stefan Stenfelt (2016). "The development of a whole-head human finite-element model for simulation of the transmission of bone-conducted sound." The Journal of the Acoustical Society of America 140.3: 1635-1651.

Paper III. You Chang, Namkeun Kim, and Stefan Stenfelt (2017). "Simulation of the power transmission of bone-conducted sound in a finite-element model of the human head."

Status : Submitted to the Journal of the Biomechanics and Modeling in Mechanobiology

Paper IV. You Chang and Stefan Stenfelt (2017). "The characteristics of different bone-conduction devices stimulated in a finite-element model of a whole human head."

Status : Manuscript 


\section{INTRODUCTION}

\section{Background of bone-conducted sound}

That not only the sound through the ears but also the vibration through the body could cause a hearing sensation has been known for many years. The hearing perception of vibrations through the body is called bone conducted (BC) sound. The $\mathrm{BC}$ sound is understood as the way vibration of the skull bones can result in a sound perception. However, BC sound also involves sound transmission in cartilages, soft tissue, the cerebrospinal fluid, and even the brain (Stenfelt and Goode, 2005a; Stenfelt, 2011).

The main usage for BC during the nineteenth century sound was to separate and diagnose the conductive component of a hearing loss, even before the concept of BC sound was understood. More systematic studies of BC sound and its mechanisms began in the early twentieth century. Important research was conducted by Georg Von Békésy (1889 - 1972). He systematically explored the concept of BC sound and showed that a BC vibration led to a basilar membrane motion in the cochlea (Békésy, 1932) and that BC sound ultimately excited the cochlea in a way similar to air conducted sound (Békésy, 1960). Tonndorf (1966) presented three basic modes by which the BC sound was transmitted to the cochlea: sound radiation in the external ear canal, inertial response of the middle and inner ear, and compressional response inside the inner ear. According to their studies, the BC sound is as important as the air-conduction sound for the hearing perception.

As one important parameter, the mechanical point impedance of the skull and its associated resonance frequency has been investigated. Since the skull bone is widely regarded as the main medium of the BC sound transmission, some studies focused on the skull and the results used to explain and understand BC sound. Franke (1956) reported the resonance frequency of the human dry skull as $820 \mathrm{~Hz}$ and $500 \mathrm{~Hz}$ when the same dry skull was filled with gelatine. Khalil et al. (1979) investigated two dry skulls from a male and a female and found 11 resonance frequencies for the male and 6 for the female in the frequency band from $20 \mathrm{~Hz}$ to $5000 \mathrm{~Hz}$. Stenfelt et al. (2000) measured a human dry skull with damping material inside and reported the resonance frequency of mechanical point impedance as 600 $\mathrm{Hz}$ at the posterior caudal part of the temporal bone, as the attachment position of the transducer for conventional bone conduction audiometry. Moreover, several investigations measuring whole heads or living humans have been done. Békésy (1951) reported the two lowest resonance frequencies of living subjects as 800 and $1600 \mathrm{~Hz}$. Håkansson et al. (1986) measured seven patients whom were equipped with titanium fixtures anchoring $\mathrm{BC}$ hearing aids in the skull bone and confirmed 
that the resonance frequencies of the human skull cannot be extracted from measures of the skin impedance. Later, Håkansson et al. (1994) presented the two lowest resonance frequencies of six live humans as 972 and $1230 \mathrm{~Hz}$ (averaged). Stenfelt and Goode (2005b) investigated six intact cadaver heads with 27 stimulation positions and reported the resonance frequencies for the mechanical impedance to be between 150 and $400 \mathrm{~Hz}$.

Investigations about $\mathrm{BC}$ sound have continued in the twenty-first century. Through the studies of the $\mathrm{BC}$ sound, it is understood that the $\mathrm{BC}$ sound transmission in the human head is complex: not only the skull bone, but also many other structures are involved in the propagation of BC sound (Stenfelt, 2013). Nowadays, more experimental data which investigated $\mathrm{BC}$ sound transmission and the responses of the BC stimulation in cadaver heads and living humans, have been reported in the literature (Stenfelt and Goode, 2005b; Håkansson et al., 1986, 1994, 2008; Eeg-Olofsson et al., 2008, 2011, 2013; Stenfelt, 2012; Reinfeldt et al., 2013). However, although the published data from human heads increased, the complexity of the experimental manipulations still limit the amount of possible experiments. Due to practical as well as ethical reasons, some experiments, which involve destructive or hazardous tests, cannot be measured directly in living human participants to investigate $\mathrm{BC}$ sound. Those kind of experiments might be possible to conduct in cadavers, but the destruction of structures and tissues might affect the $\mathrm{BC}$ sound transmission itself. Moreover, other issues are the reproducibility and comparability of experiments due to individual differences between test subjects, which can be large. The usage of models can be one way to overcome some of these issues.

\section{Introduction of the model}

Some of the drawbacks of BC experiments in live humans and cadaver heads could be solved by the use of a simulation model for BC sound. Some attempts to model the skull motion with lumped element circuit models have been done (Tonndorf, 1966; Stenfelt et al., 2000; Stenfelt and Goode, 2005b). However, those models are limited to one dimensional sound wave propagation and are often limited in the frequency range and spatial positions. Therefore, a model based on the finite element (FE) method might be a better solution.

As a numerical method for solving problems of complex structures, the FE method provides a viable simulation method in three spatial dimensions (3D). In the FE method, the model structures are divided into smaller and simpler parts, which are called finite elements, by a mesh generation technique. Therefore, a complex problem will be divided into the problems of the small and simpler elements. Through dividing an entire domain into a collection of small elements with simple equations, followed by systematically recombining all sets of element equations into a global system of equations, the entire problem can be computed. By 
subdividing the whole domain into simpler parts, the FE model can include different material properties, represent complex geometries accurately, and provide the total solution thereby capture local effects (Reddy, 1993).

A few studies have presented finite element (FE) models for BC sound simulation. Taschke and Hudde (2006) developed a FE model of the human head including the auditory periphery. Analysing the displacement and pressure distribution of the outer, middle and inner ear subsequent to a BC stimulation, they reported that the inner ear was the primary contributor to the perception of $\mathrm{BC}$ sound while the outer and middle ear played a secondary role. They also concluded that the inertial effect dominated the response of the inner ear above $1.4 \mathrm{kHz}$ and deformation of the cochlear bony shell contributed to the excitation of the inner ear. Brummund et al. (2014) developed a FE model of the human ear canal and the surrounding soft and bony tissues. Their model was used for simulations of the occlusion effect, which was reported as positive at the low frequencies and became negative at high frequencies; the change from positive to negative occurred at frequencies between 1.1 and $1.8 \mathrm{kHz}$. However, those models were a simplification of the real anatomy as they only contained bony and non-bony parts or only included a partial geometry of the heads.

Several FE models based on a human skull or whole head have been presented with the aim to analyze head injury from impact stimulation of human heads (Kleiven and Hardy, 2002; Luo et al., 2012; Ji et al., 2013; Sahoo et al., 2013). These models contain minute details of the brain. However, there is no clear evidence that the brain have a significant effect on BC sound. Therefore, these studies focused on head protection and injuries due to skull trauma but not on the BC sound transmission. Moreover, Yang et al. (2008) developed a model with a threelayer skull bone and the cerebral spinal fluid (CSF). But that model is still not suitable for the BC sound simulation, since some important tissues or structures, like the ear canal and cartilages which can influence the propagation of BC sound were omitted (Stenfelt and Goode, 2005a).

Consequently, a new FE model, which focused on BC sound transmission, would be necessary. The main goal of this $\mathrm{PhD}$ project is to develop a FE model that mimic a real human head's dynamic properties for simulation of BC sound transmission. This model can then be used to investigate fundamentals of BC sound transmission and get a better understanding of how BC works. The model could also guide experiments and reduce experimental cost. Moreover, some experiments, which are difficult to conduct experimentally, were performed using this FE model. Those results could be used to improve diagnosis and therapy. Moreover, the model can be used to develop and optimize any BC-related device, such as hearing aids, diagnostic tools, consumer products, or ear protectors. 


\section{MODELING AND VALIDATION}

Through the Visible Human Project ${ }^{\odot}$ (http://vhnet.nlm.nih.gov/), cryosectional images of an adult female cadaver head were obtained and used to reconstruct the geometry of the FE model. The original cryosectional images have a resolution of $0.33 \times 0.33 \times 0.33 \mathrm{~mm}$. To get the intact geometry of the human head, 703 images were used, from the top of the head to the bottom of the chin. The geometries of all the structures are obtained from those cryosectional images (Fig. $1)$.

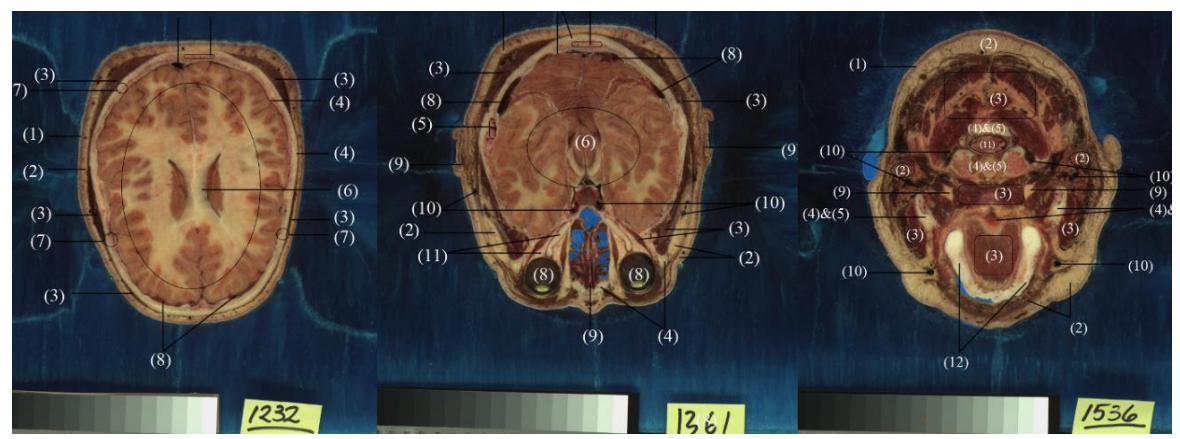

Figure 1. Examples of cryosectional images with numbers indicating the identification of the structures.

According to the above, the main structures that could influence BC transmission in the head were divided into eight domains. After extracting the geometry of each domain, the geometries were imported into Hypermesh ${ }^{\odot}$ (Altair Engineering, Troy, MI, USA). The meshes for different structures in the FE head model were created by Hypermesh $^{\odot}$. The commercial FE software, ACTRAN ${ }^{\odot}$ (Free Field Technologies, Belgium) and COMSOL Multiphysics ${ }^{\circledR}$ (COMSOL Inc., Stockholm, Sweden), were used for the simulation.

\section{The first model: Dry skull model (Paper $I)$}

As the skull bone is believed to be the most important pathway for BC sound, a dry skull model could show some important characteristics of BC sound transmission. Therefore, a 3D FE model of a human dry skull was developed. The dry skull model, as a simplified model, was used to verify the validity of the modeling method and evaluate relevant software for FE analysis. Moreover, the skull model could be used as a part of the development of a whole head model. 


\section{Modeling}

The geometry of the human skull was obtained through the cryosectional images from the Visible Human Project ${ }^{\odot}$. The study by Stenfelt et al. (2000) with vibration measurements in three perpendicular directions was chosen for validation of the FE model parameter values. According to Stenfelt et al. (2000), a layer of polyurethane, approximately $5 \mathrm{~mm}$ thick, was added inside the cranial vault to attenuate the resonances in the dry skull. It was here included in the FE model to be consistent with the experiment. The 3D FE human skull model is shown in Fig. 2, which has a continuous mesh of 32000 tetrahedron solid elements (each with four nodes) for the skull and 18000 for the polyurethane.
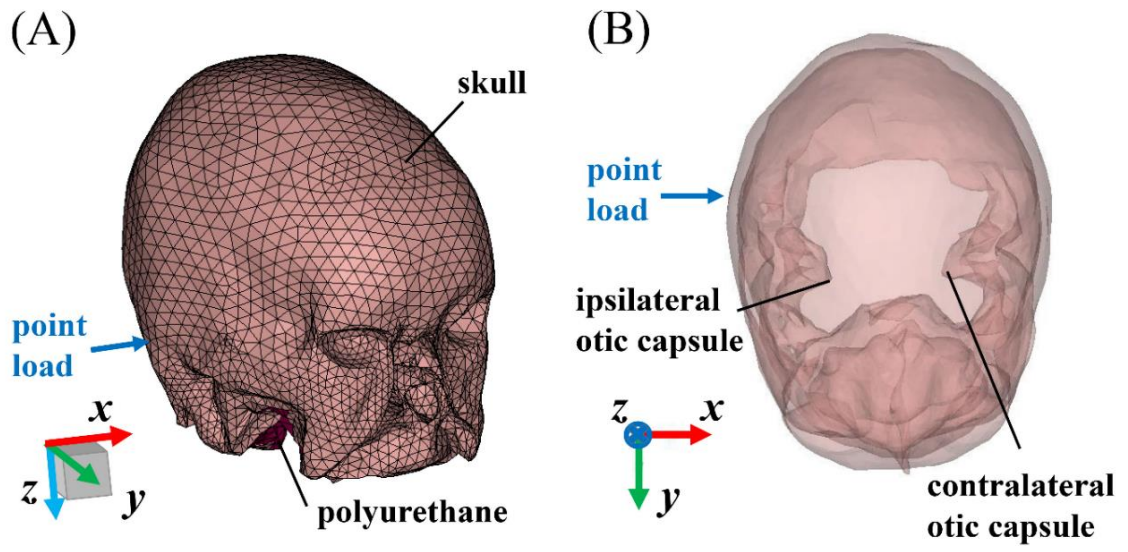

Figure 2. (A) The geometry of the dry skull model shown as finite-element meshes of the skull and polyurethane. (B) Top view of the skull model. The cranial vault and the attached polyurethane are here transparent to allow visualization of the cochlear bone (Kim et al., 2014).

The mass of the skull and the polyurethane were set as $470 \mathrm{~g}$ and $380 \mathrm{~g}$ according to the experimental data in Stenfelt et al. (2000). The parameter values for the material properties of the skull model were identified from the literature as in vitro or in vivo data on the human ( Sahoo et al., 2014; Asgharpour et al., 2014).

\section{Validation and Results}

One parameter that was used to validate the FE model is the mechanical point impedance. One reason for using this metric is the large amount of experimental data presenting the mechanical point impedance, on dry skulls, cadaver heads, and in live humans. For the FE dry skull model, the mechanical point impedances in Stenfelt et al. (2000) were used but there are several studies that report investigations of the mechanical point impedance in dry skulls (e.g. Franke, 1959; Khalil et al., 1979; Stalnaker et al., 1971; Stenfelt et al., 2000). 
The coordinate system for the simulations was the same as in the Stenfelt et al. (2000) study (shown in Fig. 2). The stimulation positions were at $35 \mathrm{~mm}$ behind the ear canal opening in the medial direction (as $x$-axis in Fig. 2), considered as the mastoid position. The mechanical point impedance at the stimulation positions is displayed in Fig. 3. The results of the mechanical point impedance in Fig. 3 do not only show the validation between the simulation and experiment, but also display the influence of the Young's modulus on the simulation results, when a single parameter was changed. Since the mass was reported in the experiments, the density was fixed, based on the volume of the model.

Another metric that have been experimentally investigated for BC sound transmission in the human skull is the cochlear response with BC stimulation. Stenfelt et al. (2000) investigated the acceleration response of the bone encapsulating the cochlea during BC stimulation at the mastoid and forehead on a dry skull. Similar to the experiment, two measurement positions were used, on the otic capsule close to the ampulla of the posterior semi-circular canal (close to the cochlea), at both sides of the skull. Only the mastoid was used as the stimulation position, and the

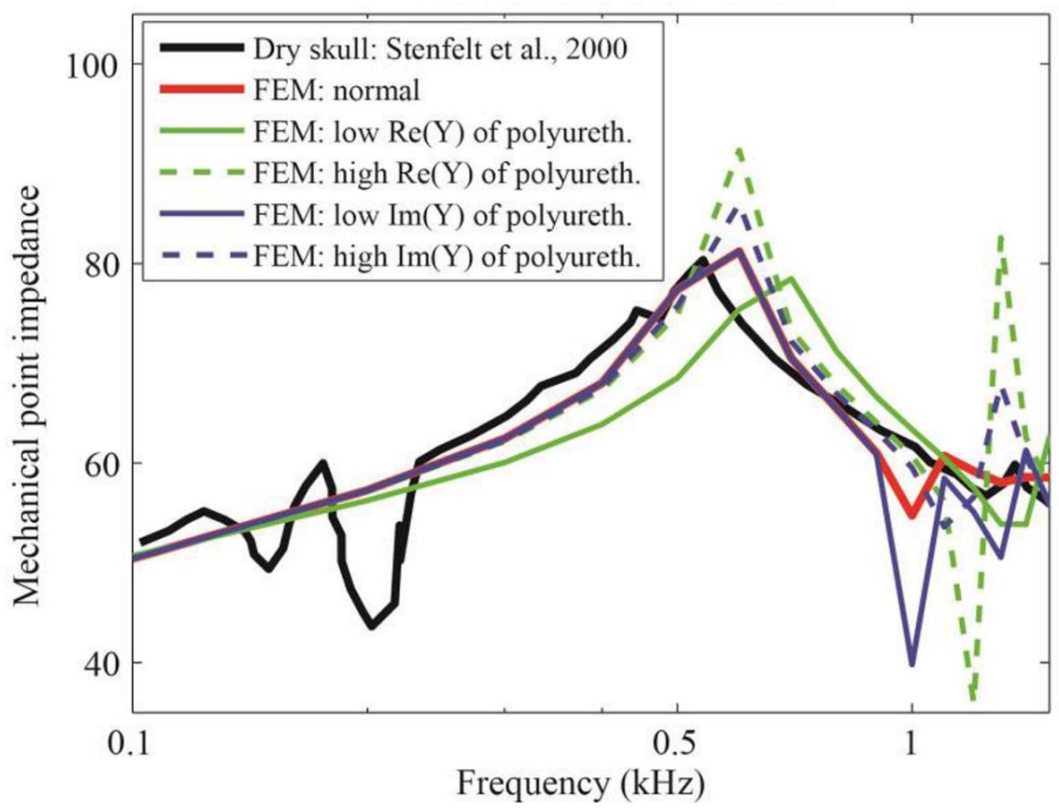

Figure 3. Level of the mechanical point impedance of the dry skull. The black solid line represents the experimental data from Stenfelt et al. (2000) and the solid red line (normal) is the result with the optimized values in the model. The Young's modulus of the polyurethane was altered by increasing or decreasing its real $(\mathrm{Re})$ or imaginary $(\mathrm{Im})$ part by two orders of magnitude. For example, the complex Young's modulus, $\{\mathrm{A}+\mathrm{Bi}\}$, is $\{1 \mathrm{e} 6+1 \mathrm{e} 4 \mathrm{i}\}$ for the 'normal', 'high $\operatorname{Im}(\mathrm{Y})$ ' means $\{1 \mathrm{e} 6+1 \mathrm{e} 6 \mathrm{i}\}$ (Kim et al., 2014). 
responses obtained from the measurement positions are shown in Fig. 4. The results shown are the average values of from both sides in three perpendicular directions.

Although there are differences between the FE model and real skulls as the simulation results deviates from the experimental data, the dry skull FE model show some characteristics of BC sound propagation. Since the bony part of the head is normally considered as the main medium of the BC sound transmission, this study could be extended to studies of human cadavers or living humans.
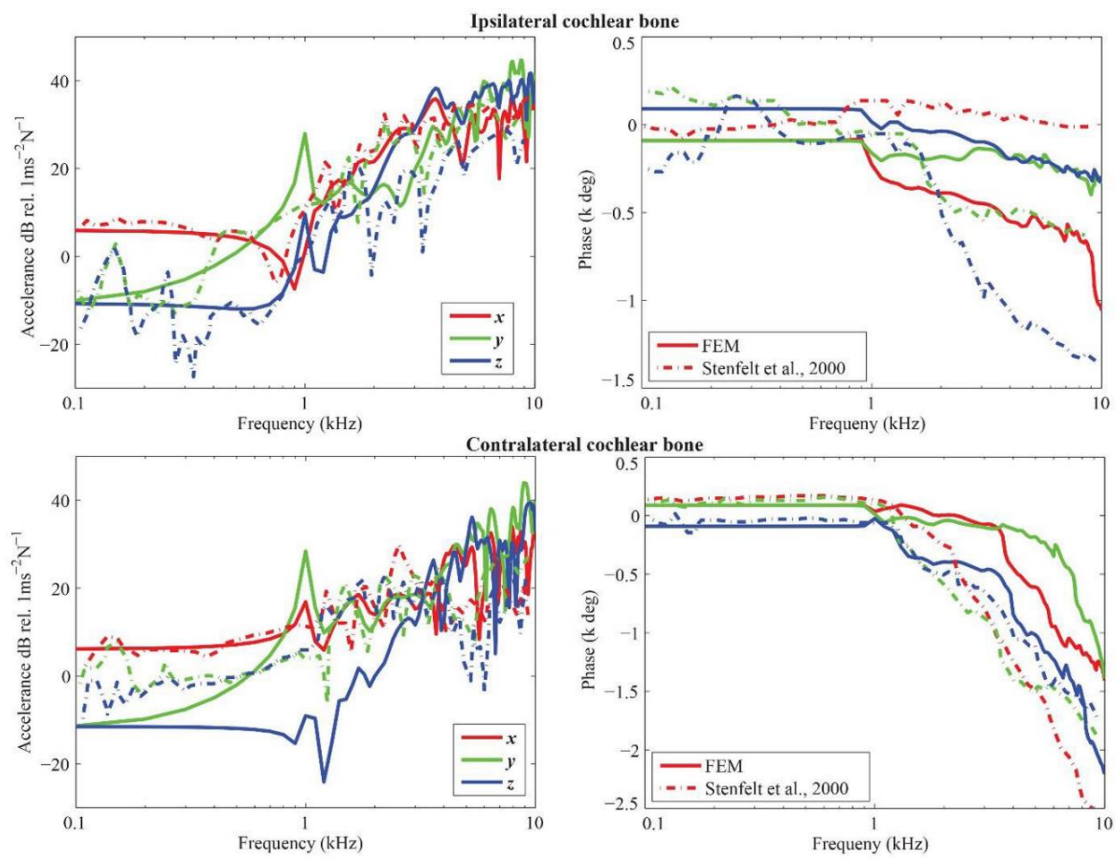

Figure 4. Level and phase of the acceleration at ipsilateral and contralateral sides of the cochlear promontories. For all panels, the red, green, and blue lines represent the $\mathrm{x}$ (medial-lateral), y (anterior-posterior), and $\mathrm{z}$ (inferior-superior) directional acceleration. In addition, solid lines indicate the results of the simulation while dashed-dotted lines show the experimental results (Kim et al., 2014).

\section{The second model: Whole head model (LiUHead) (Paper II)}

This study is an extension of the first paper. As the dry skull model could show parts but not all characteristics of the BC sound propagation in the human head, the aim of this study was to develop a new model which contained more details of the human head. 


\section{Modeling}

The geometry of the head was also obtained from the Visible Human Project ${ }^{\odot}$. As the examples of cryosectional images shown in Fig. 1, each structure and tissue was annotated, then the geometries were imported into Hypermesh ${ }^{\odot}$ and a mesh of the head geometries obtained. According to the resolution of the cryosectional images and the main structures and tissues which can influence BC transmission (Stenfelt and Goode, 2005a), eight domains were included in the whole head model (also called as the LiUHead) (1. brain tissue, 2. cerebrospinal fluid (CSF), 3. eyes, 4. inner ears, 5. cartilages, 6 . cortical bone (including teeth), 7. spongy bone (diploë), and 8. soft tissues (see Fig. 5).

The structure of the skull or head was reconstructed and the size of each part was adjusted according to the real dimension (Fig. 6). The final FE model consists of 87,000 nodes and 481,000 tetrahedron elements (four-nodes).

The values of the material parameters for each part of the head model were identified from published data on experimental measures of human material properties or human models. In here, the CSF, eyeballs and the inner ears were considered as liquid or filled with liquid, and simplified to have the same properties as water (Levin et al., 1981). The bony parts of the LiUHead have significantly different Young's modulus compared to the dry skull model. Based on the experimental data of fresh human bone, the Young's modulus of cortical bone was $4 \mathrm{GPa}$ (McElhaney et al., 1970; Motherway et al., 2009; Auperrin et al., 2014) and the Young's modulus for the diploë was set to 0.4 GPa (Keaveny et al., 1997; Jaasma et al., 2002; Hamed et al., 2012). It should be noticed that the real human skull is composed of several bones, and according to the experimental data from Auperrin et al. (2014), the parameters vary with the different parts. However, taking into account the simulation time and the hardware requirements, those specific details were not included in this version of the LiUHead. The brain also consists of several parts, and has been modeled as a hyperelastic or viscoelastic material with high Poisson's ratio (close to 0.5 ) in most FE head models for head injury simulations (Kleiven and Hardy, 2002; Luo et al., 2012; Sahoo et al., 2013). However, there is no data showing the brain to be an important medium for the BC sound transmission. Therefore, the brain was set as one domain in the LiUHead. Moreover, the brain was modeled as an elastic material with low Young's modulus, since the stimulation intensity of $\mathrm{BC}$ sound is low and the structure of the brain is intact during the excitation, when compared with the excitation level used in head injury models. 
(A)

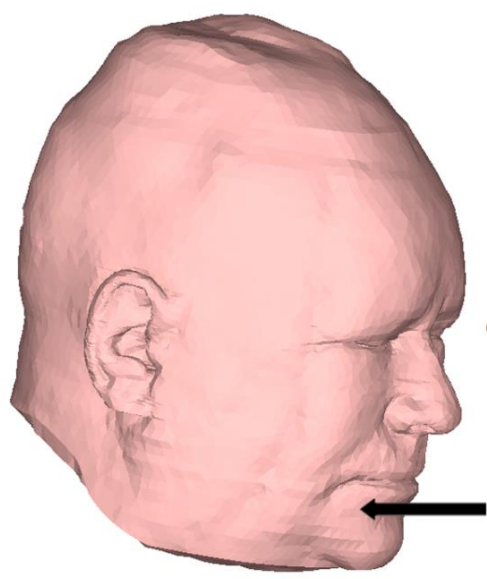

(C)

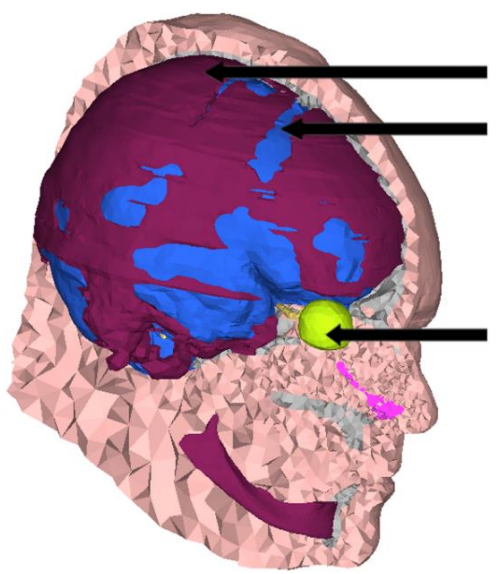

(B)

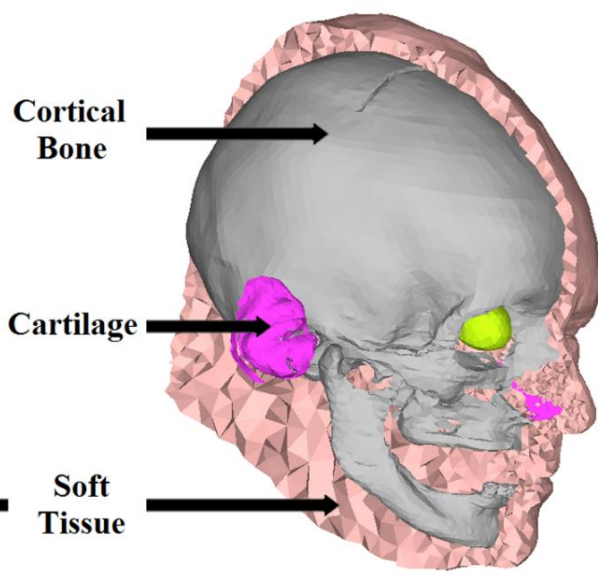

(D)

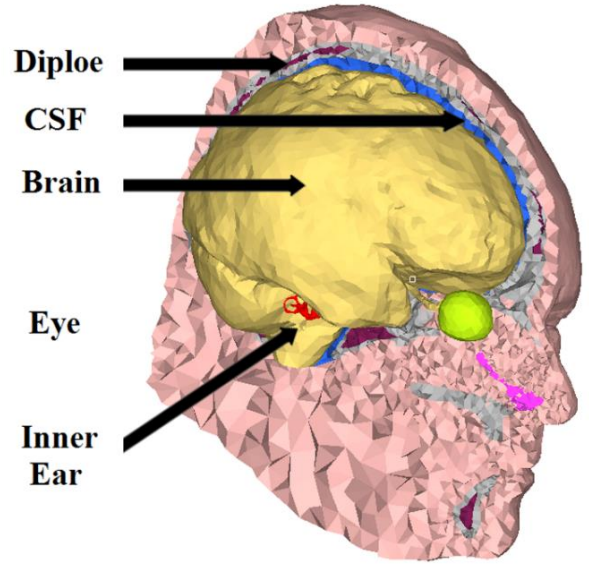

Figure 5. The images show the components of the FE whole head model (LiUHead). A) Outer skin layer of the head which is treated as soft tissue. B) The soft tissue is removed to expose the cranium (bone) and cartilage. C) and D) The skull bone is removed to show the CSF, brain tissue, eye and also the position of the inner ear. Also indicated is the diploë that is positioned between the inner and outer cortical bone giving the skull bone a sandwich structure (Chang et al., 2016). 

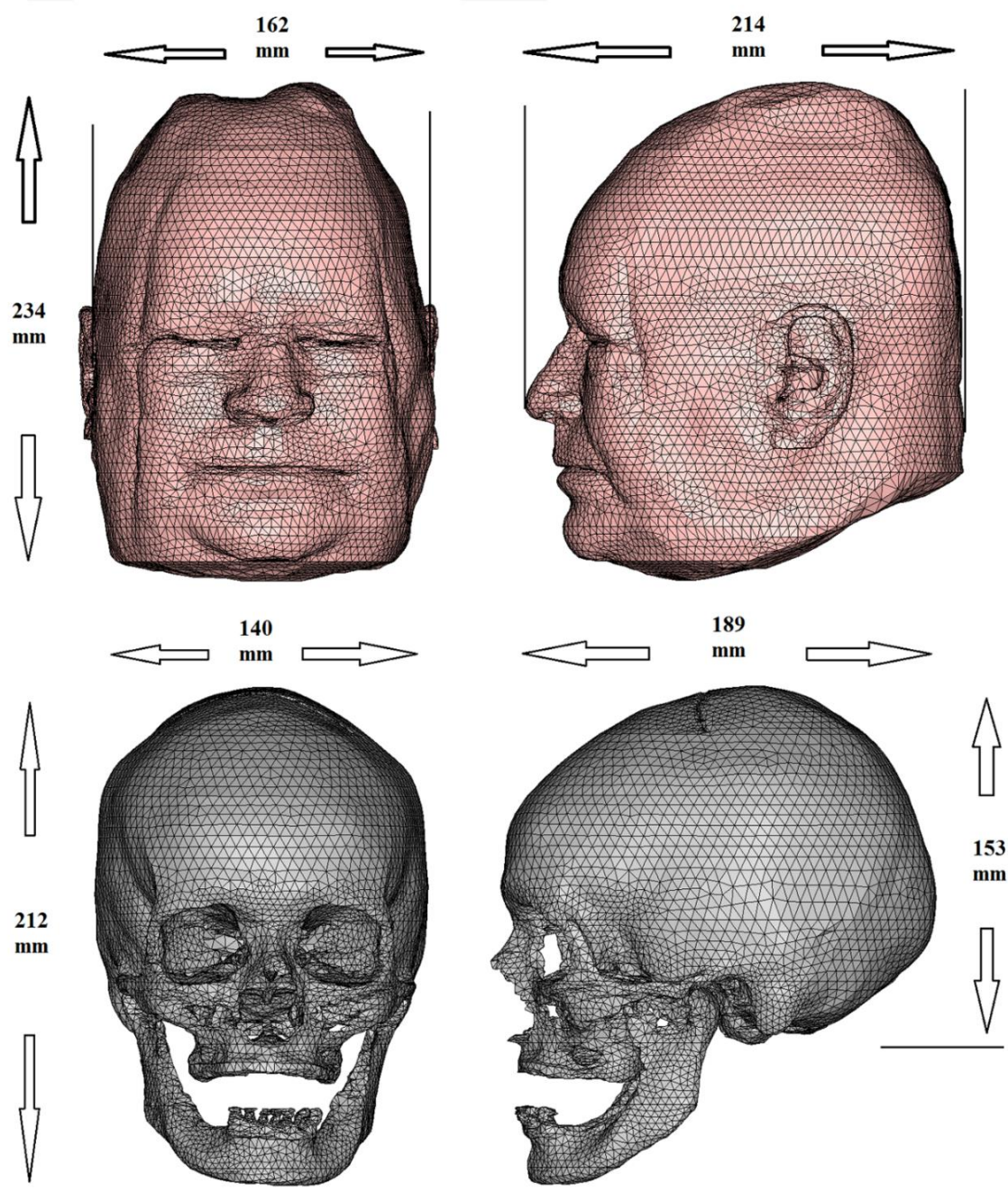

Figure 6. The structures and the sizes of models were reconstructed, adjusted and meshed by Hypermesh $^{\odot}$ (Chang et al., 2016).

\section{Validation and Results}

The coordinate system for the current study was the same as in the experimental study of Stefan and Goode (2005b), which measured the resulting vibrations at the cochlear promontory in three perpendicular directions. There were seven stimulation positions in total. Three symmetrical stimulation points were located at the sides of the head and one was at the forehead, see Fig. 7. One position was termed the BAHA position (Tjellström and Håkansson, 1995) which is the position where normally a BAHA implant is situated and that corresponded to the 
(A) Ipsilateral Stimulation Positions

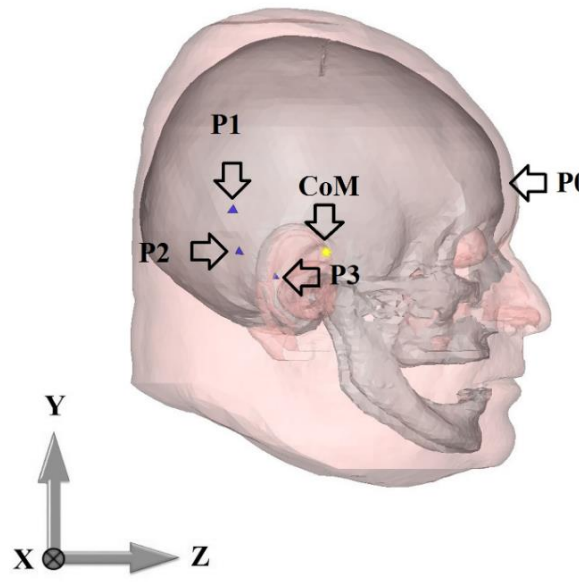

(B) Measurement Positions

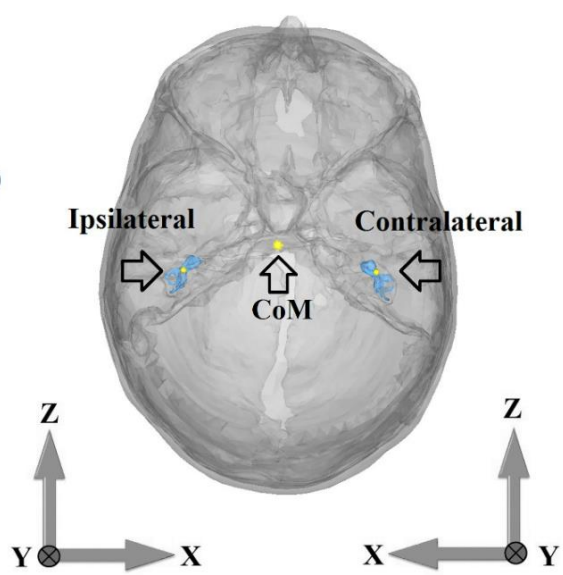

Figure 7. (A) The stimulation positions at the ipsilateral side and (B) the measurement positions on the ipsilateral and the contralateral cochlear promontories. The position for the center of mass is also indicated (Chang et al., 2016).

setting of Eeg-Olofsson et al. (2008, 2011 and 2013) and Håkansson et al. (1986, 1994).

The results of mechanical point impedances were the averaged values when stimulated from both sides, and single values with stimulation from the forehead. The simulated data were compared to experimental data from live subjects (Håkansson et al., 1986) for the BAHA position, and data measured in cadaver heads (Stenfelt and Goode, 2005b) for other positions. Due to the head-neck junction, the influence of the body is insignificant for frequencies above $400 \mathrm{~Hz}$ (Stalnaker et al., 1971). Although the head-neck junction might affect the results at low frequencies, it was here assumed that the simulations were not affected by this when validated with the experimental data obtained from living humans.

The validation data of the cochlear responses were in one direction (the lateralmedial direction, same as the direction of the stimulation) obtained from cadaver heads by Eeg-Olofsson et al. $(2008,2011)$ and live humans Eeg-Olofsson et al. (2013) when stimulated at BAHA position, and in three perpendicular directions with data from cadaver heads by Stenfelt and Goode (2005b) when stimulated at other positions (see Fig. 8). Moreover, the transcranial transmission and transcranial accelerance were validated with the experimental data from cadaver heads by Stenfelt and Goode (2005b) and living subjects by Håkansson et al. (1994). The overall tendencies of all the simulation results show a great agreement with the experimental data. 


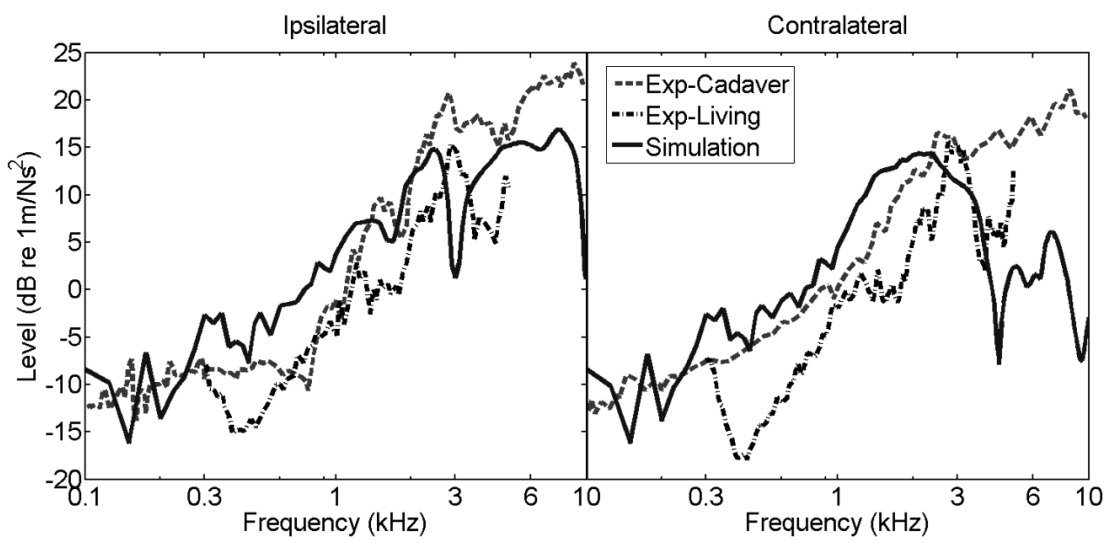

Figure 8. An example of the average accelerance (acceleration/force) measured at the cochlear promontory when stimulated at BAHA position (Chang et al., 2016). The solid lines show the simulation results, the dashed lines present the experimental data from cadavers and the dasheddotted lines display the data obtained from living humans.

A parameter sensitivity test was also conducted. When a single parameter was changed 10 times by increasing it or decreasing it, the mechanical point impedance and the cochlear promontory acceleration were compared with the original one. The variation of the density and the Young's modulus significantly influenced the results while the Poisson's ratio (for solid domains) and sound speed (for fluid domains) gave less than $1 \mathrm{~dB}$ alteration at any measured frequency.

To validate that the mesh of the model was fine enough at the high frequencies, a mesh convergence analysis of the LiUHead was conducted. The model was remeshed in Hypermesh ${ }^{\oplus}$ decreasing element numbers by $4.4 \%$ and $6 \%$ and increasing the element numbers by $12.8 \%$. When the mechanical point impedance and the cochlear promontory acceleration were compared with the original results, the deviation was up to $3 \mathrm{~dB}$ at $0.3 \mathrm{kHz}$ and less than $1 \mathrm{~dB}$ at other measured frequencies. This means that the element numbers in the current version of the LiUHead is sufficient for simulations up to $10 \mathrm{kHz}$.

Although the simulation results of the LiUHead might not match for a specific subject, the LiUHead can simulated average behavior for BC sound and can be used to understand BC sound transmission. Moreover, this model can achieve testing and comparison that is destructive or unavailable for testing in cadaver heads and living humans. 


\section{INVESTIGATIONS USING THE LIUHEAD}

The BC sound transmission have been studied for over a century, but the complete picture of hearing by BC sound has not yet been achieved (Stenfelt et al., 2000). Reasons for this is that destructive manipulation prevent some experiments, and limited number of test subjects and individual differences lead to deviations of repetitive and comparative experiments thus obscuring the results. However, those issues, which are difficult to test in experiments, would be easy to achieve using the LiUHead.

In the thesis, two applied investigations were studied with the LiUHead. One is the $\mathrm{BC}$ power distribution and transmission of $\mathrm{BC}$ sound, and the other is a comparison of the characteristics of different bone-conduction devices (BCDs). For the investigations, the LiUHead was restructured with Hypermesh ${ }^{\odot}$ and simulated by COMSOL Multiphysics ${ }^{\circledR}$ (COMSOL Inc., Stockholm, Sweden). In order to confirm the consistency of the simulations with the previous research, the simulation results of the COMSOL Multiphysics ${ }^{\circledR}$ were compared with the results from the ACTRAN $^{\odot}$. When the settings were the same, the simulations shown almost the same results between those two FE solvers. The frequency resolution was $25 \mathrm{~Hz}$ in the range of 100 to $500 \mathrm{~Hz}, 50 \mathrm{~Hz}$ in the range of 500 to $1000 \mathrm{~Hz}$ and $100 \mathrm{~Hz}$ in the range of 1 to $10 \mathrm{k} \mathrm{Hz}$.

\section{Power distribution and transmission (Paper III)}

Hearing by $\mathrm{BC}$ is usually described as sound power transmitted through the body (Stenfelt, 2013). But vibratory power transmission in a living human or a cadaver head is difficult to measure. The exact pathways conveying the sound power have not been clarified. However, by the simulation of the LiUHead, the computed BC power and the power flux could indicate the role of the different head-structures and tissues in the power transmission, and determine dominant BC power transmission pathways for BC sound in the human head.

\section{Settings}

The LiUHead with the same material parameters as in Chang et al. (2016) was simulated in this study. The eight domains of the LiUHead were grouped into three different structures to ease computations and interpretations. The three parts were: (1) the soft tissue and cartilages located outside of the skull bone, (2) the skull bone comprising two layers of cortical bone interposed with one layer of diploë, and (3) 
the brain and CSF including the eye balls and inner ear fluids, located inside the skull bone.

The excitation is provided at the mastoid skull bone, where a triangular prism shaped metal piece was used to simulate a screw implanted through the outer layer of the cortical bone and the diploë. The stimulation was applied as a dynamic force on the screw with a magnitude of 1 Newton. The stimulation position and coordinate system are shown in Fig. 9.

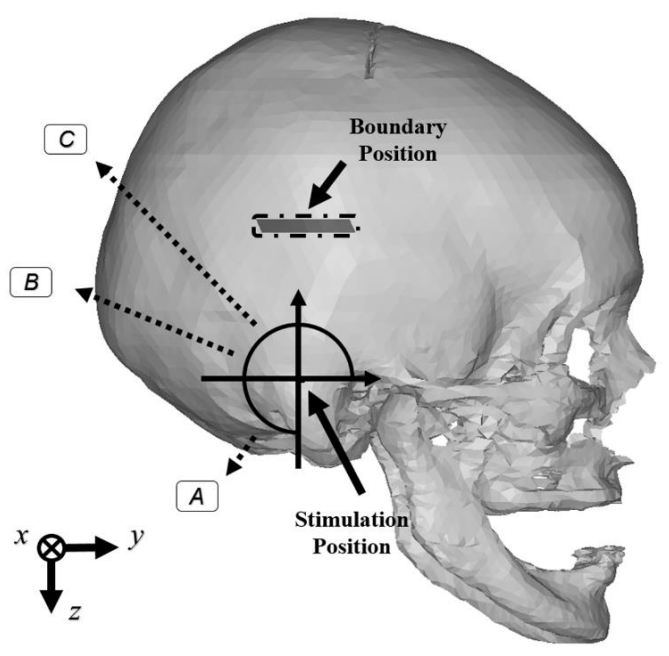

Figure 9. Ipsilateral view of the skull bone. An artificial circle around the stimulation position was used for measurements of radially transmitted $\mathrm{BC}$ power. The gray area superior to the stimulation position shows one of the boundaries between the skull bone and skull interior.

To investigate the $\mathrm{BC}$ sound power transmitted in the skull bone radially from the stimulation position, an artificial circle was created, with approximately $20 \mathrm{~mm}$ radius around the stimulus position on the skull bone (Fig. 9). There are 14 measurement positions with the radiation direction from the center to the circle. Due to the anatomy of the skull, the measurement positions were limited to the range from 0.12 to 4.01 radians (approximately 7 to 230 degrees), corresponding to approximately $2 / 3$ of the circle. The thickness of the bone at each measurement position differed. Therefore, the area, which the power flux flows through at each measurement point, is defined as the thickness of the skull multiplied with a width of $1 \mathrm{~mm}$.

Moreover, to investigate the $\mathrm{BC}$ sound power transmission through the skull interior, two boundaries between the inner layer of the skull bone and the brain/CSF on both sides were selected, marked as the gray area surrounded by a dashed-dotted line in Fig. 9. The boundaries investigated were randomly selected in the widest region of the skull, but not including the stimulation position, since the forced excitation at the stimulation position causes local skull bone deformation that might lead to local effects of the interaction between the skull and skull interior. 


\section{Results and conclusion}

The bony part has often been considered as the main medium for the $\mathrm{BC}$ sound transmission. However, there are no previous studies of the distribution of BC power in different structures. In this study, the LiUHead was simulated in a free boundary condition along the edges, which means that the values outside the boundary of this model should be considered equal to zero (Lee, 1980). Therefore, there is no external force or applied torque was loaded except the stimulation. According to the stimulation, the input power to the LiUHead is

$$
P_{\text {inp }}=\frac{1}{2} \operatorname{real}(\mathbb{F} \cdot \mathbb{V})
$$

Here, $\mathbb{F}$ is the applied complex stimulation force and $\mathbb{V}$ is the resultant complex velocity of the stimulation surface. When the thermal power loss was ignored, $P_{i n p}$ should equal to the sum of the power flow in each part, which is computed as

$$
P_{p f}=\frac{1}{2} \operatorname{real}(\sigma \cdot(i \omega \varepsilon))
$$

where $\sigma$ is the stress tensor, defined as the pressure acting on an area, $\varepsilon$ is the strain tensor, $\omega$ is the angular frequency, and $i$ is the imaginary unit.

The power flow in the skull part is slightly lower than that in the soft tissue below $1 \mathrm{kHz}$, but shows the highest power flow above that frequency, see Fig. 10. There is no direct experimental data to confirm the importance of the soft tissue and cartilage for $\mathrm{BC}$ hearing at low frequencies. But some studies have shown that the ear canal sound pressure with BC stimulation was dominated by the sound radiation from the soft tissue and cartilage part of the ear canal at low frequencies (Stenfelt et al., 2003; Stenfelt and Reinfeldt, 2007). Another whole head simulation study also reported similar conclusions (Taschke and Hudde, 2006). Those results also indicate that the importance of vibration transmission in the soft tissues diminish with frequency compared to the vibration transmission in the skull bone. Since the skull bone part has the least volume of the structures investigated, the bony part have the highest BC power density. Therefore, the skull bone is the most important media for $\mathrm{BC}$ power transmission and indicates the great capability for $\mathrm{BC}$ sound, hence its name. The current simulations indicate that sound power inside the brain tissue exist during $\mathrm{BC}$ stimulation, but they cannot predict the importance of the intracranial sound power for hearing $\mathrm{BC}$ sound. 


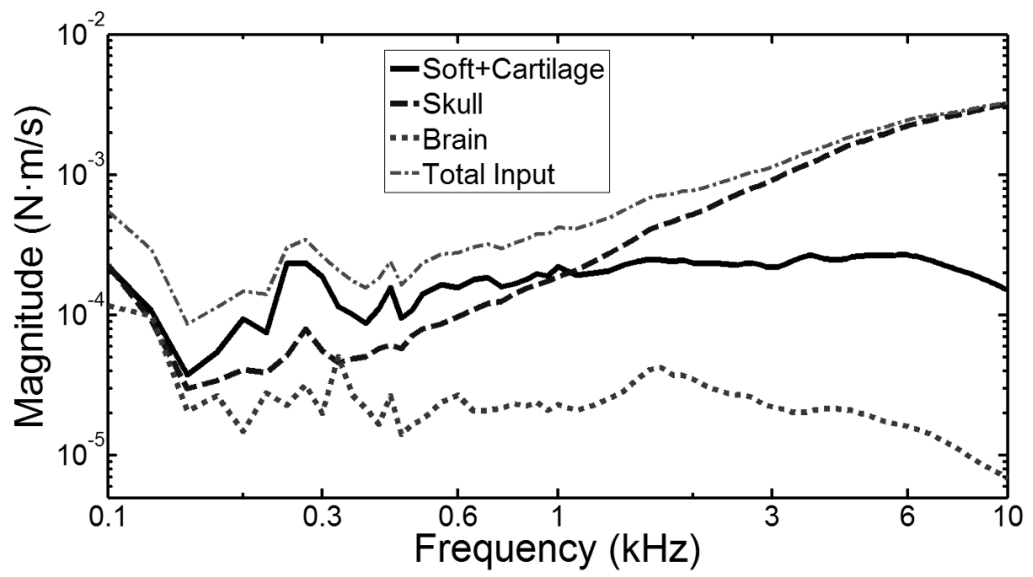

Figure 10. The power flow in the skull, soft tissue (include cartilage) and skull interior analyzed, shown as a solid line, dashed line and dotted line, respectively. The total input is displayed as the dashed-dotted line.

The whole measured frequency range was divided into three bands: low frequencies (from 100 to $600 \mathrm{~Hz}$ ), mid frequencies (from 600 to $3 \mathrm{k} \mathrm{Hz}$ ), and high frequencies (from 3 to $10 \mathrm{kHz}$ ). When the radially transmitted power in the skull bone around the stimulation position was investigated, as Fig. 11 show, most power of the $\mathrm{BC}$ sound in the skull bone is concentrated to the skull base, close to the foramen magnum, displayed as the pathway A in Fig. 9. Moreover, two other pathways with local maxima goes through the occipital bone, shown as pathway B and $\mathrm{C}$ in Fig. 9.

Several authors have presented the BC sound transmission through the skull. They primarily show the transcranial BC sound transmission, but do not elude on the BC pathways or directions (Stenfelt et al., 2000, Eeg-Olofsson et al., 2008, 2011, 2013; Stenfelt and Goode, 2005b; Stenfelt, 2011, 2012). In this study, the $\mathrm{BC}$ power flux through the pathways were analyzed. The three pathways identified in Fig. 9 were between the stimulation position and the corresponding position at the contralateral side, according to the transmission directions. These pathways are imaginary and it is not suggested that this is the only way the BC sound is transmitted from one side to the other. However, it gives an indication of how the $\mathrm{BC}$ sound power alters from one side to the other. In general, the BC sound power inline with the pathway direction decreases with distance and the rate of the decrease is greater at high than at low frequencies. 


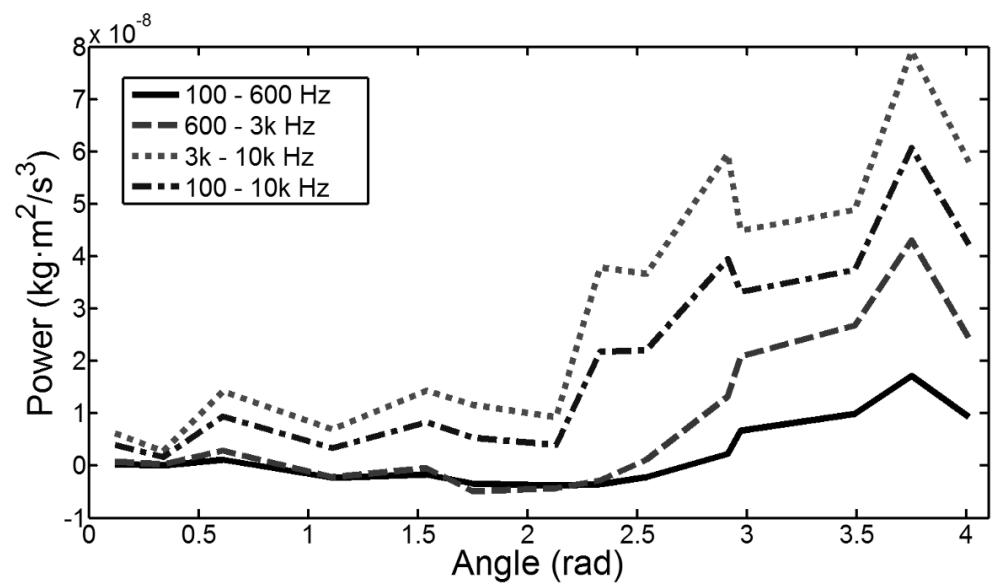

Figure 11. BC outward power fluxes at a circle around the stimulation position. The solid line, dashed line and dotted line display the results in the low, mid and high frequencies, respectively. The dashed-dotted line is the mean values of the whole frequency range. The powers at all four frequency ranges have a maximum at the measurement position at 3.75 radians. A local maximum is seen for the whole frequency range at 2.91 radians and another local maximum is found at 2.33 radians.

The skull interior is normally not considered important for $\mathrm{BC}$ hearing. Although there is $\mathrm{BC}$ sound power transmitted from the skull bone to the interior, the current study cannot predict the importance of the intracranial sound power for hearing $\mathrm{BC}$ sound. The power flux transferred through the non-excitation area (as the boundary shown in Fig. 9) are 3 order less than the BC power transmitted from the skull bone to the skull interior at the excitation position. Even if $\mathrm{BC}$ power is transmitted from the skull to the brain at the stimulation position, there seem not to be efficiently transmitted through the brain tissue to the opposite side.

\section{Characteristics of Bone-conduction Devices (Paper IV)}

The aim of this BC study is to compare positions and applications used for bone-conduction devices (BCDs) for BC stimulation in the human. There is a growing numbers of $\mathrm{BCDs}$ available for communication, hearing rehabilitation, and hearing testing. According to the interface of the $\mathrm{BC}$ transducer and the skull, the BCDs can be categorized as skin-drive BCDs where the transducer is attached to the skin, or direct-drive BCDs where the transducer is rigidly coupled to the skull bone (Reinfeldt et al., 2015).

Since the different BCDs have different geometries and masses, are connected to the skull using unequal methods, and are located at different positions of the head, it is difficult to have a general method to compare different BCDs. Moreover, 
due to the implantation method of some BCDs, comparative tests within the same subject is not possible. Moreover, comparative tests between different subjects is affected by individual differences. The LiUHead could overcome those issues. In addition, in many cases, the BCDs were evaluated by testing and reporting thresholds and speech perception abilities. The simulation of the LiUHead might reveal details of the differences in BC sound transmission and the influences of the specific attachments between the device and the head.

After minor adjustments and reconstruction, four kinds of skin-drive BCDs, three kinds of direct-drive BCDs, and one in-the-mouth device (considered as a kind of direct-drive $\mathrm{BCD}$ ) were simulated using the LiUHead. By the simulations and evaluations of the $\mathrm{BC}$ sound transmission from the interface between the $\mathrm{BCD}$ and skull and the inner ears, the BC sound characteristics of different BCDs were compared. The results reveal influences from the position and attachment method on the $\mathrm{BC}$ excitation of the inner ears.

\section{Settings}

Eight different BCDs were simulated: Radioear B71 (Radioear, US); Adhear ${ }^{\circledR}$ (MedEL, Austria); Sophono ${ }^{\circledR}$ (Medtronic, US); Baha ${ }^{\circledR}$ Attract (Cochlear, Australia), Bone conduction implant (BCI); Bonebridge ${ }^{\mathrm{TM}}$ (MedEl, Austria); BAHA (Cochlear, Australia) and Ponto (Oticon Medical, Sweden), and SoundBite ${ }^{\mathrm{TM}}$ (Sonitus Medical Inc, US). They were all simulated using the interface between the BCDs transducer and the head, excluding the specific details of the transducers and amplifying electronics. The LiUHead was assumed symmetrical and all BCDs were located on the right side. All BCDs were excited by a 1 Newton dynamic force that was applied on the output signal position of each BCD. Similar to previous studies, the vibration of the cochlear promontories at both sides were used to estimate the cochlear excitation.

Three skin-drive BCDs have the transducer located at the outside of the head, and attached to the skin surface by a static force from magnets or a headband. The soft tissues under the BCDs would be deformed by the action of the static force and the local material parameters are altered (Cortés, 2002). The Radioear B71 was held in place by a static force from a headband of at least 5.4 Newtons (in the current study set as 6 Newtons). The Sophono ${ }^{\circledR}$ was attached by a magnetic retention system, here modelled as a static force of 3 Newtons. Similar to the Sophono ${ }^{\circledR}$, the Baha ${ }^{\circledR}$ Attract System was also held by the mutual attraction of magnets. Since the largest size of the Baha ${ }^{\circledR}$ Attract System was modelled, a static force of 4 Newtons were used. According to the study of Cortés (2002), the soft tissue material properties between the BCD interface and the skull bone were locally changed based on the mechanical point impedances in experimental data for static forces between 3 to 6 Newtons (see Fig. 12). 

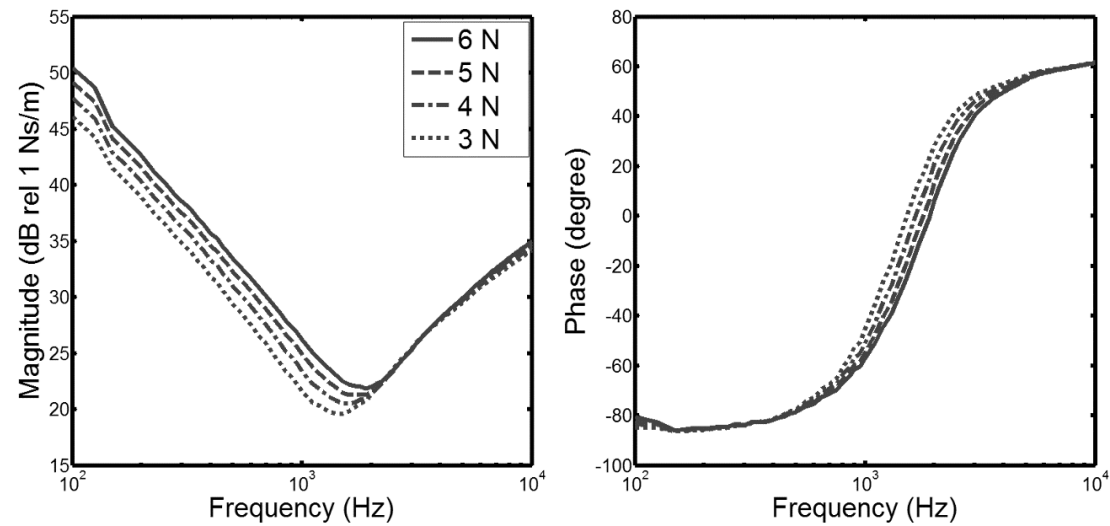

Figure 12. The mechanical point impedances of the B71 with the parameters for simulations of different static forces.

\section{Results and conclusion}

The mechanical point impedances of each BCD measured at the stimulation position are presented in Fig. 13. The mechanical point impedance have only been presented for a few BCDs, like the Radioear B71 and BAHA/Ponto, while the mechanical point impedance of other systems in living humans is lacking. This means that the mechanical point impedances obtained from the LiUHead are novel for some of the BCDs. These results provides an understanding of the local structure motion and can be helpful to design and improve the BCDs.

Except for the Radioear B71 and BAHA/Ponto, most BCDs were investigated by testing the sound stimulation in relation to hearing thresholds. Those results do not only rely on the vibration response from the cochleae, but the data are affected by the function of the transducer, amplification settings and also the sensitivity of the persons' hearing. In the current study, the level of the total accelerances (squared sum of the three orthogonal accelerations divided by the stimulation force) of the cochlear promontories were used as outcome measure, shown in Fig. 14. The responses of each $B C D$ with the same force stimulation indicated the transmission of BC sound to the cochleae. Those results show the efficiency of BC sound transmission for the different BCD designs. For example, the levels of all BCDs below $0.5 \mathrm{kHz}$ are similar. Therefore, the low frequency results from clinical studies do not depend on the BC sound transmission but on other parts of the $\mathrm{BCD}$ design, such as the transducer or amplifier. In addition, in general, the skindrive BCDs decrease more than the direct-drive BCDs at frequencies above $3 \mathrm{kHz}$. Consequently, the transducers and amplifiers for the skin-drive BCDs should compensate for this at the high frequencies. 

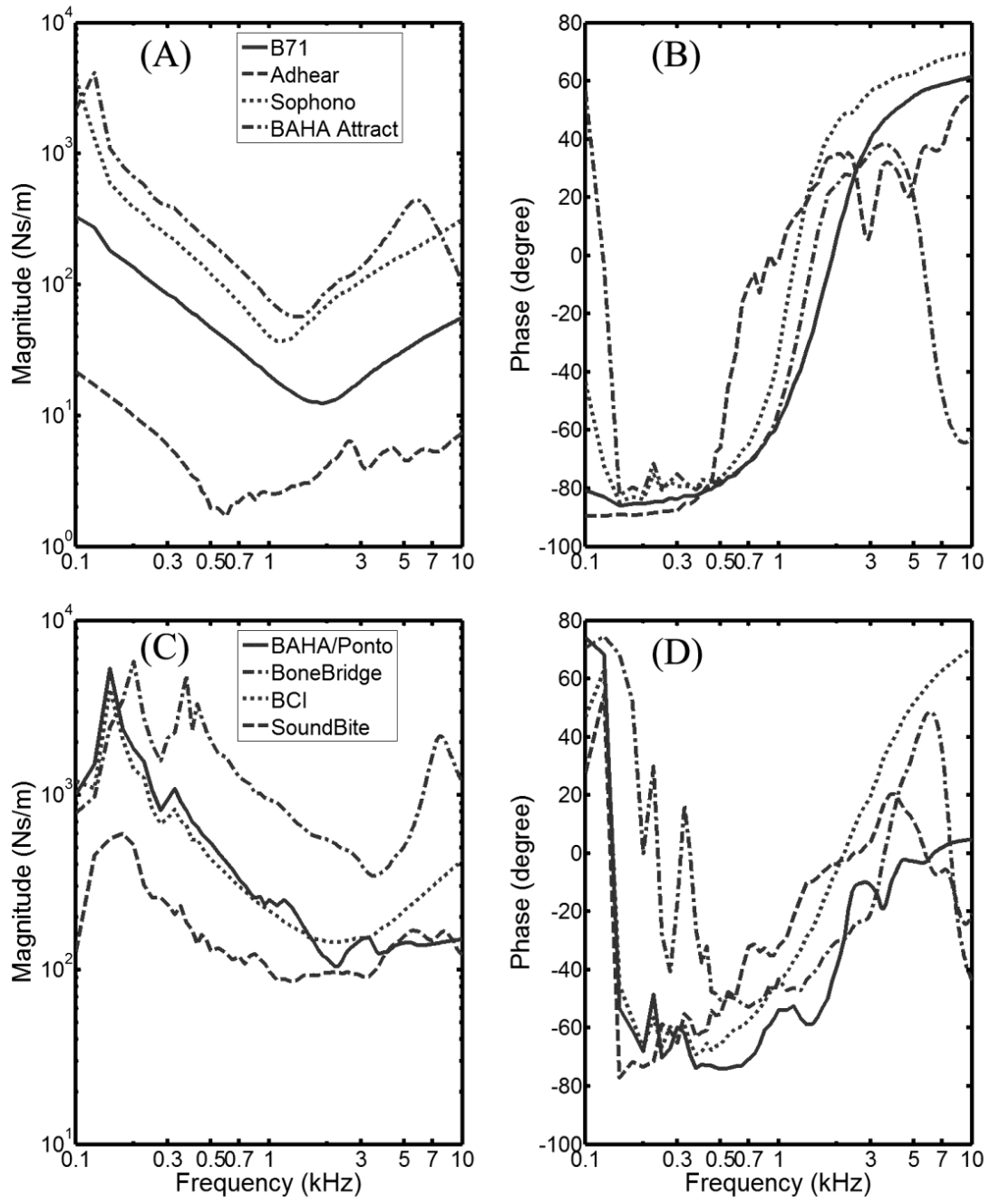

Figure 13. The mechanical point impedance of each $\mathrm{BCD}$ shown as magnitude (left) and phase (right). The skin-drive $\mathrm{BCDs}$ displayed in (A) and (B), and the direct-drive $\mathrm{BCDs}$ (include in-themouth device) shown in (C) and (D). 

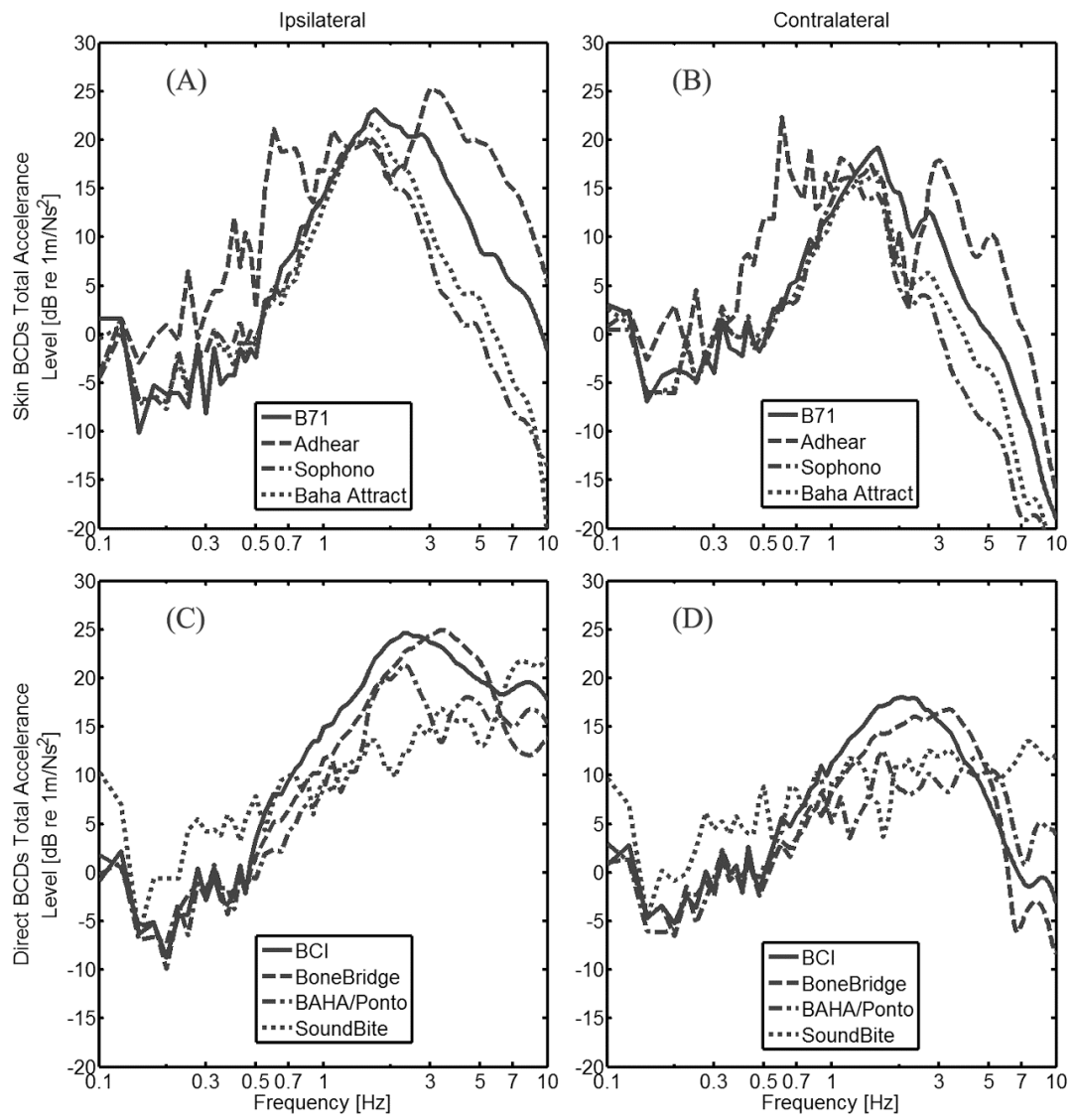

Figure 14. The level of the total accelerances from the BCDs at the ipsilateral (A, C) and contralateral $(\mathrm{B}, \mathrm{D})$ cochlear promontories.

In reality, the valid comparison between the BCDs is the ability to provide a hearing sensation from an equal electric stimulation level. Since the stimulation is the vibration output from the transducer, two transducer models, Radioear B71 (Lundgren, 2011) and BAHA/Ponto, were included. As a result, the cochlear responses of all BCDs with the same electric stimulation (here a 1 volt to the transducer was used) are presented in Fig. 15. Because the BAHA/Ponto, as a percutaneous BAHA, was the first available direct-drive BCD and probably the most powerful BCD device today (Reinfeldt et al., 2015), other BCDs have often been compared with the BAHA/Ponto. Moreover, due to the easy application, the Radioear $\mathrm{B} 71$, as the audiometric BCD, with a headband or softband is also used as the gold standard when assessing other BCDs. But except those two BCDs, there are few comparisons between other BCDs. During this study, all eight BCDs were compared with each other. In general, the direct-drive BCDs show similar responses with an equal electric stimulation level with the $\mathrm{BCI}$ and Bonebridge ${ }^{\mathrm{TM}}$ as slightly 
better compared with the others. And the direct-drive BCDs are more effective at frequencies above $3 \mathrm{kHz}$ than the skin-drive BCDs. The Sophono ${ }^{\circledR}$ and $\mathrm{Baha}^{\circledR}$ Attract gave similar cochlear responses as the BAHA/Ponto at frequencies up to 2 $\mathrm{kHz}$. The Radioear B71 showed the highest response levels at low frequencies but the lowest levels at the high frequencies. The Adhear ${ }^{\circledR}$, however, presented the lowest responses of all BCDs at most of the frequencies.

Although the simulation results do not completely represent the clinical and experimental evaluations of the BCDs as the transducer models are not the same as the real transducers in the BCDs, the results provides insight to the function of the different types of BCDs when also including a transducer to drive the system.
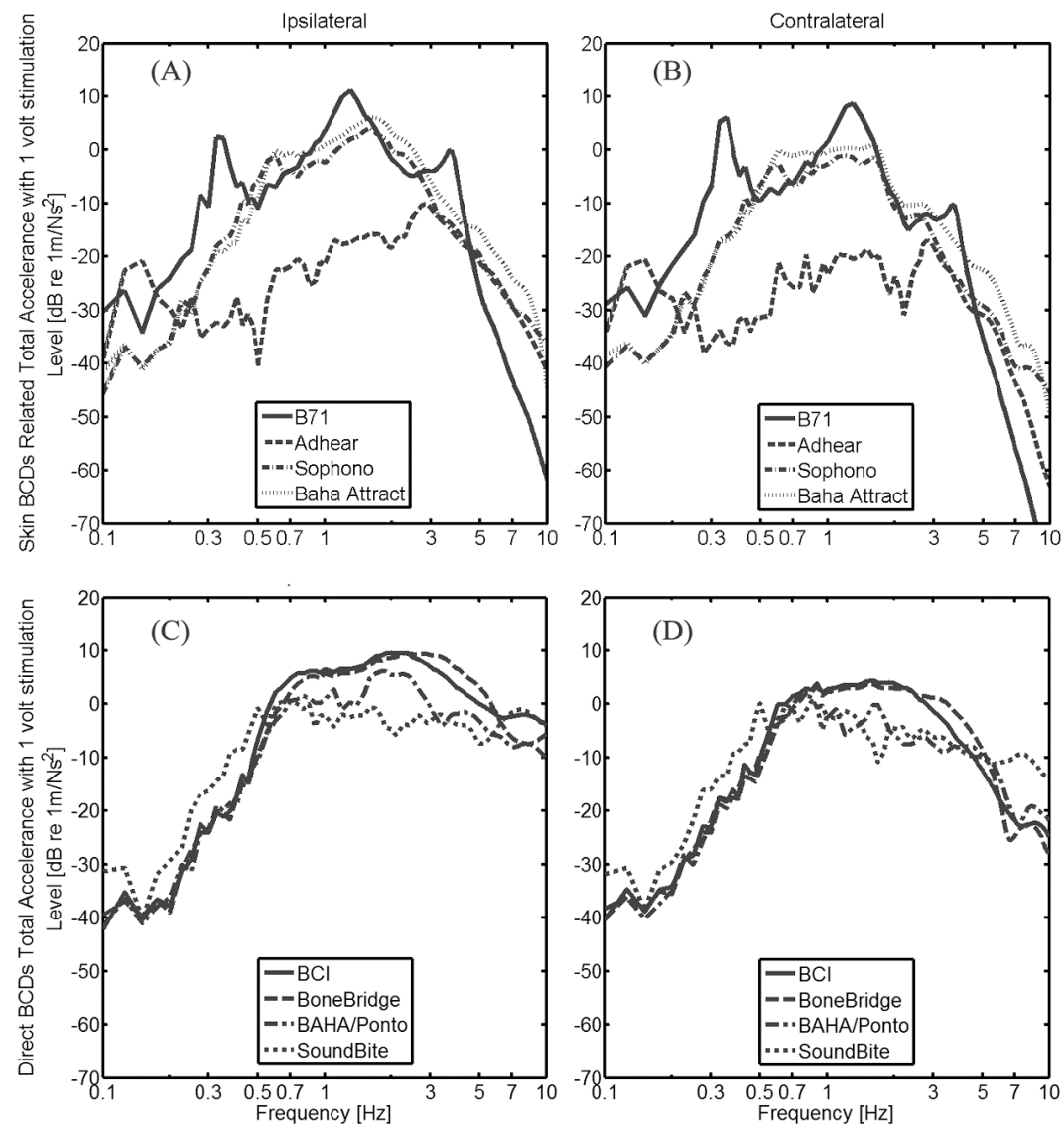

Figure 15. The total accelerances of the BCDs with 1 volt stimulation, shown as (A) and (B): skin-drive $\mathrm{BCDs},(\mathrm{C})$ and $(\mathrm{D})$ : direct-drive $\mathrm{BCDs}$, ipsilateral results in the left panels and contralateral results in the right panels. 


\section{CONCLUSION}

\section{Summary}

In this thesis a FE model of the human head was presented where the geometry was obtained from cryosectional images of a real human and the parameters of the model were fitted according to experimental data. This FE model, termed the LiUHead, is the only whole head model developed for simulation of BC sound. The LiUHead includes all major elements believed to influence the transmission of the BC sound (Stenfelt, 2013). The validation showed that the LiUHead can reasonably represent experimentally and clinically measured data in the live human and cadaver heads. Moreover, the LiUHead could predict and estimate BC sound transmission in the human, and assist in the design and improvement of BCDs.

The beginning of this thesis gives the information of the models' design. In a dry skull model, the design of the geometry and the effect of the parameters were tested, and the model was validated against related experimental data. Based on the dry skull model, the LiUHead, a whole head model with more details than the dry skull model, evolved. The LiUHead could not only reproduce experimental measurements in live humans and cadaver heads, but also investigate mechanisms of BC sound transmission.

Furthermore, the LiUHead could be used for experiments which are difficult to measure, or even immeasurable. Due to the characteristic of the FE model, a structure which cannot be measured, or a position which is difficult to measure in reality, is not a problem. Although there might not be any experimental data of the exact type for comparison, the LiUHead has been validated in general and the simulation results should be usable. Such simulation results can give insight to future experiments and explain phenomena obtained in experiments.

The final part of this thesis presented an application of the LiUHead in the field of BCDs. Due to the attachment methods of some BCDs, a hearing test could only be conducted after the $\mathrm{BCD}$ was implanted. If the input-output function of the BCDs are known, for example the transducers frequency response function and the amplifier gain, the simulation results of the LiUHead with different BCDs offer a possibility for patients with a hearing loss to choose a BCD suitable for their situation. Furthermore, the LiUHead also provides a tool to test design and improvement of BCDs and decrease the evaluation time of new devices. 


\section{Future Research}

The LiUHead provides a tool for simulation of several research problems that are difficult or time consuming to test on cadavers or living humans, and also to understand the mechanisms of $\mathrm{BC}$ sound transmission.

\section{Effect of the skin/soft tissue thickness and transducer attachments area}

During the investigations in paper III, the soft tissue next to the skull bone could not be ignored for $\mathrm{BC}$ sound transmission. Moreover, through the characteristics of the BCDs (paper IV), the skin-drive BCDs were different from the directdrive BCDs. This indicates that the soft tissues, especially in the local area near the stimulation position, plays an important role for $\mathrm{BC}$ sound transmission. Some experimental data from Mattingly et al., (2015) indicated the effects of the skin/soft tissue thickness on cochlear input signal when the BCDs were used. Seven cadaver heads were involved and four soft tissue flaps with 0 (no flap), 3, 6 and $9 \mathrm{~mm}$ were used. The response magnitudes were similar at 0 and $3 \mathrm{~mm}$ but significantly decreased with greater thickness of the soft tissue flaps $(6$ and $9 \mathrm{~mm})$ at high frequencies, above $4 \mathrm{kHz}$.

The effect of the skin thickness is easily investigated in the LiUHead. For example, a Radioear B71 on the mastoid skin was used as the stimulation unit. The soft tissue flap between the Radioear B71 and skull surface was adjusted to various thicknesses. The original soft tissue thickness of the LiUHead is about $13 \mathrm{~mm}$. Based on that thickness, the local soft tissue flap of the LiUHead under the Radioear B71 transducer were adjusted and to four sizes: 4, 6, 8 and $10 \mathrm{~mm}$, an example is shown in Fig. 16. The responses of the BC stimulation at the cochlear promontory can then be obtained with stimulation using the different thicknesses.

The area of the transducer attachment surface can influence the BC sound transmission. According to the characteristics of the BCDs (paper IV), the area of the Sophono ${ }^{\circledR}$ is about 4 times larger than the interface area of the Radioear B71. When the same static force was applied to the Radioear B71 (see the results with

(A)

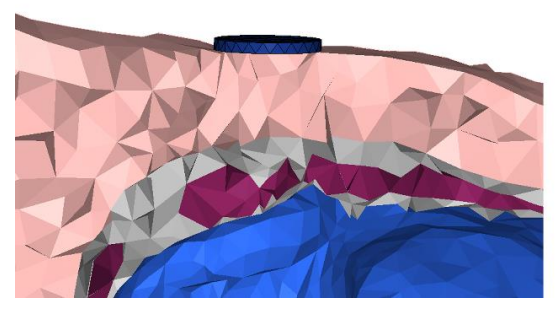

(B)

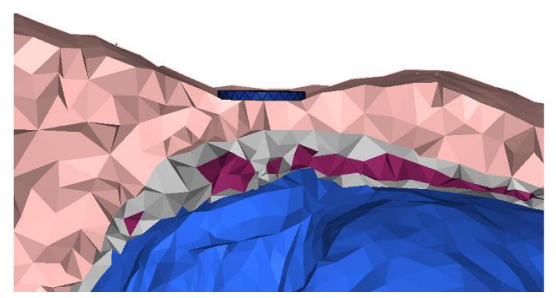

Figure 16. An example of the local soft tissue thickness, as (A) $13 \mathrm{~mm}$ (original size) and (B) 6 $\mathrm{mm}$. 
3 Newtons in Fig. 12), the impedance magnitude of the Sophono ${ }^{\circledR}$ was also around 4 times higher than that of the Radioear B71. Rigato et al., (2018) presented responses of the cochlear promontory obtained from four cadaver heads with two flat direct-drive implants of different sizes. They reported that the smaller contact surface might provide better transmission of $\mathrm{BC}$ vibrations at mid and high frequencies. Those studies indicate that the transducer attachments area has an effect of the $\mathrm{BC}$ transmission. However, the proportion between the attachments area and the cochlear responses was not clear.

The LiUHead could also investigate the effect of the attachments area. The Radioear B71 has normally a diameter of $15 \mathrm{~mm}$. That area was modulated to different sizes, a larger size of $20 \mathrm{~mm}$ diameter, and smaller sizes as 10 and $5 \mathrm{~mm}$ diameter were modelled. The cochlear responses can be simulated and the effect of the transducer attachments area indicated with equal input stimulation.

\section{Transcranial attenuation and time delay}

Transcranial attenuation and time delay are important parameters of BC sound that influence binaural hearing with bilateral bone conduction hearing aids (BCHAs) and the efficiency of BCHAs in unilateral deafness (Stenfelt, 2006; Stenfelt and Zeitooni, 2013). Transcranial attenuation could be simulated by using the LiUHead. When the two most common stimulation positions were used as stimulation positions, the mastoid and the BAHA position, simulations in the frequency domain were conducted, and the results of transcranial attenuation are displayed in Fig. 17. At low frequencies, the transcranial attenuation is close to $0 \mathrm{~dB}$ and above $1 \mathrm{kHz}$ the attenuation increases with frequency. With stimulation at the mastoid, the transcranial attenuation is about 20 to $25 \mathrm{~dB}$ at 5 to $10 \mathrm{kHz}$. When stimulated at the BAHA position, the transcranial attenuation is close to $10 \mathrm{~dB}$ lower than at the mastoid in the same frequency range.

Most simulations of the LiUHead were done in the frequency domain. In the frequency domain the time delay can be calculated from the phase if it has a smooth response (no resonances or anti-resonances). Some previous studies reported the time delay by calculating the phase differences in cadavers (Stenfelt and Goode, 2005b) and living subjects (Purcell et al., 2003; Mcleod and Culling, 2017). However, the calculated results had large fluctuations indicating a non-smooth phase. Therefore, simulations in the time domain could provide better results, and the LiUHead offers the possibility to simulate directly in the time domain. When an impulse stimulation was loaded at one side at the mastoid position at $1 \mathrm{kHz}$, the velocity responses of the cochlear promontories following the stimulation direction is shown as an example in Figure 18. The results in Fig. 18 shows a time difference between the two responses. More simulations and analysis is required to reveal the time delay over a larger frequency range. 


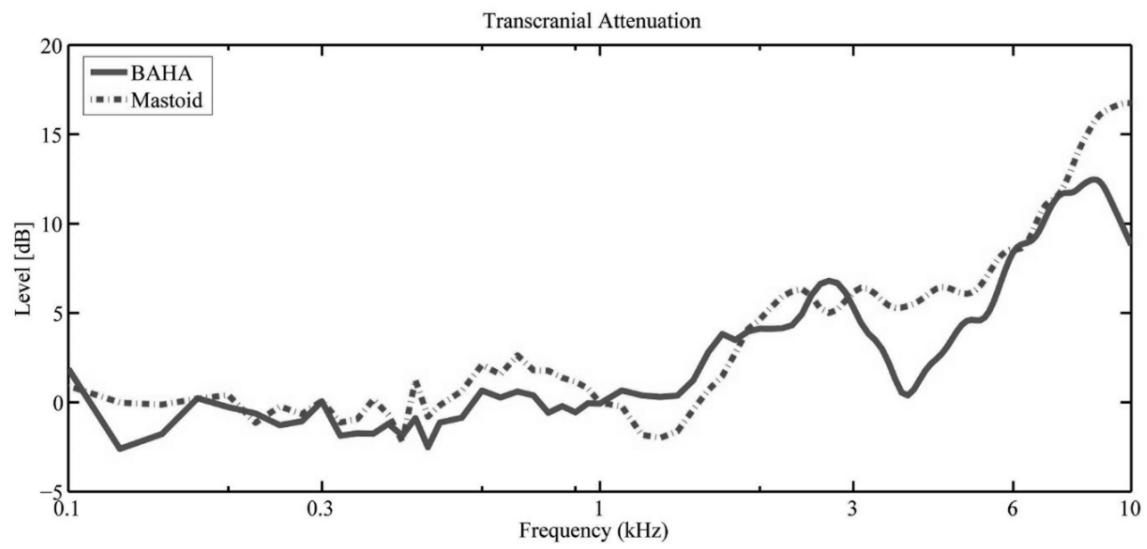

Figure 17. The level of the transcranial attenuation. The solid line was with stimulation at the BAHA position and the dash-dotted line was with stimulation at the mastoid.

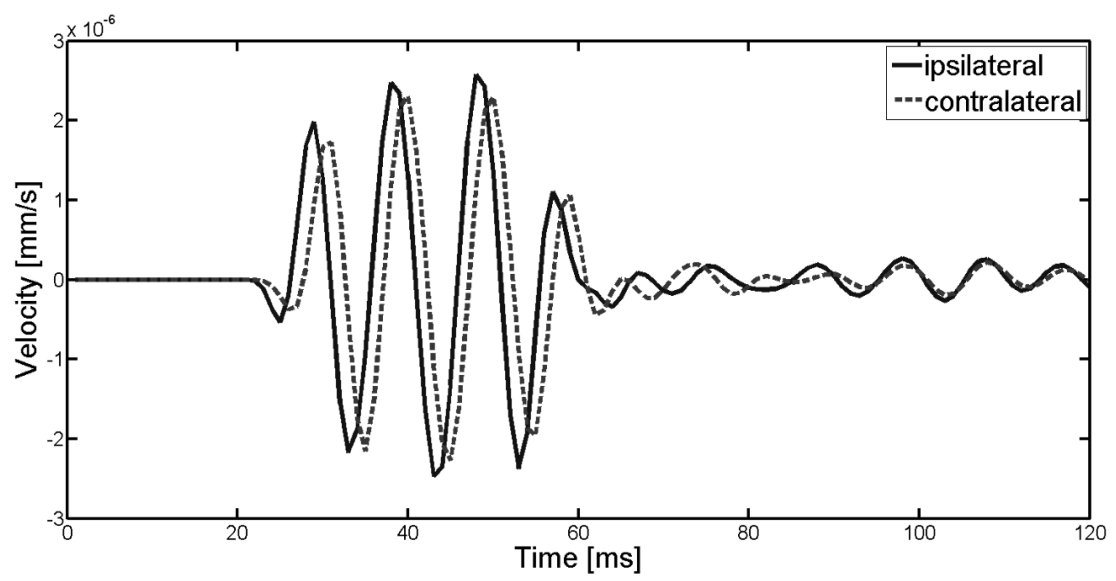

Figure 18. The velocity responses of cochlear promontories in the time domain for a $1 \mathrm{kHz}$ burst. The solid line shows the ipsilateral side and the dashed line shows the contralateral side.

\section{Detailed inner ear}

Finally, the responses of the BC sound excite the inner ear and result in a hearing sensation based on a mechanical force to neural excitation (Steele et al., 2000). Through the vibration of the basilar membrane inside the inner ear, the sensory cells would be excited and result in an auditory perception (Dallos, 2012). There inner ears in the LiUHead are fluid filled ducts with simple geometry. However, due to the limited resolution of the cryosectional images, no detail was included.

In the future, a middle and inner ear model with more details might be developed from cryosectional images with high resolution, and added into the LiUHead. 
However, since the geometry information of the detailed cochlea would be impossible to be obtained from the same subject as the LiUHead. Due to individual differences, the inner and middle ear models should be adjusted to fit the size and structure of the LiUHead. Another possible solution would be used the vibratory response around the temporal bone area in the LiUHead as the general input for other FE models of the inner ear. For example, Kim et al. (2013) published a 3D FE model of the human auditory periphery including a coiled-cochlea model and Sakellarios et al. (2017) presented 3D cochlea geometries using human microCT images. Such models could be used to investigate inner ear responses based on vibratory patterns obtained in the LiUHead. Thus, with BC stimulation provided by the LiUHead, the basilar membrane response in those models could be obtained for an external stimuli. 


\section{ACKNOWLEDGEMENTS}

Back in 2013, one day in April, I received an email when I was on a business trip, and a few days later, I got an interview in a hotel room with a non-perfect internet connection. At that time, I did not realize that interview would bring me back to Sweden and start an amazing time as a $\mathrm{PhD}$.

It would not have been possible to finish this doctoral thesis without the help and support of many people. To begin, I would like heartfelt thanks to Professor Stefan Stenfelt, my main supervisor, for giving me this opportunity to carry out this $\mathrm{PhD}$ position in Linköping University, helping me to broaden my knowledge, providing me an excellent advising for not only the research, but also my career. I especially thank his understanding at the hardest and darkest time of my life. I greatly appreciate his support, knowledge, expertise, patience, and his eccentric but lovely sense of humour. It has been a privilege to work under his supervision, and I hope I would have the honour to have more opportunities to cooperate with him after this $\mathrm{PhD}$.

I gratefully acknowledge my co-supervisor, Assistant Professor Namkeun Kim, for sharing his knowledge and experience for research. His guidance and suggestions helped me to understand my topic and follow my research quickly at the beginning of $\mathrm{my} \mathrm{PhD}$, and his assistance and patient are invaluable. I would like to thank Professor Torbjörn Ledin and Professor Bo Håkansson, for their inspiring comments and as the committee of my halftime seminar.

This doctoral journey, which took almost five years, gave me the chance to meet many interesting people including fellow post-doc and PhD students, who I do not name here, but the memories will last forever. I would like to use this opportunity to thank the all the helping from Birgitta Larsby, Mehrnaz Zeitooni, Amin Saremi, Johanna Hengen, Sumru Keceli, who was or is working in our division and research group. I specially thank Anna-Karin Strömberg, for her helping during my tough time. I am particularly grateful to Elaine H.N. Ng for her thoughtful comments, her helpings during my $\mathrm{PhD}$ life and the pleasant talking and discussions we had. A special thank you goes to the administrators at the division for taking care of all $\mathrm{PhD}$ students, including me.

I am grateful to the financial support of the EU project termed "Semantic Infostructure interlinking an open source Finite Element tool and libraries with a model repository for the multi-scale Modelling and 3d visualization of the inner-ear" (SIFEM). It is a fantastic experience to cooperate with the people in the SIFEM. I 
would like to thank Steve Elliott and Guangjian Ni, for sharing their knowledge and helping my research.

I would like to say thank you and love you to my mother and grandma. I cannot imagine I could complete this $\mathrm{PhD}$ without their love and support. I also thank my father, I love him so much and forever. "La tristesse durera toujours". I would show my great grateful to my families and friends in China and Sweden, and all over the world who have supported me. Finally, I thank my cousin, Yicheng Wang, for helping me to design the wonderful cover. 


\section{REFERENCES}

Asgharpour, Z., Baumgartner, D., Willinger, R., Graw, M., \& Peldschus, S. (2014). Research Paper: The validation and application of a finite element human head model for frontal skull fracture analysis. Journal of the Mechanical Behavior of Biomedical Materials, 33(Forensic Biomechanics), 16-23.

Auperrin, A., Delille, R., Lesueur, D., Bruyère, K., Masson, C., \& Drazétic, P. (2014). Geometrical and material parameters to assess the macroscopic mechanical behaviour of fresh cranial bone samples. Journal of Biomechanics, 47, 1180-1185.

Brummund, M. K., Sgard, F., Petit, Y., \& Laville, F. (2014). Three-dimensional finite element modeling of the human external ear: simulation study of the bone conduction occlusion effect. The Journal of the Acoustical Society of America, 135(3), $1433-1444$.

Chang, Y., Kim, N., Stenfelt, S. (2014). The development of a whole-head human finite-element model for simulation of the transmission of bone-conducted sound. (2016). Journal of the Acoustical Society of America, (3), 1635-1651.

Cortés, D. (2002). Bone Conduction Transducer: Output Force Dependency on Load Condition. Chalmers University of Technology, 13-14.

Dallos, P. (2012). Overview: Cochlear Neurobiology. In Springer Handbook of Auditory Research: The cochlea. Ed. Fay, R. R., Popper A. N., Dallos, P., Springer, New York. pp 1-43.

Eeg-Olofsson, M., Stenfelt, S., \& Granström, G. (2011). Implications for contralateral bone conducted transmission as measured by cochlear vibrations. (2011). Otology and Neurotology, (2), 192-198.

Eeg-Olofsson, M., Stenfelt, S., Taghavi, H., Reinfeldt, S., Håkansson, B., Tengstrand, T., \& Finizia, C. (2013). Transmission of bone conducted sound-correlation between hearing perception and cochlear vibration. Hearing Research, 306, 11-20.

Eeg-Olofsson, M., Stenfelt, S., Tjellström, A., \& Granström, G. (2008). Transmission of bone-conducted sound in the human skull measured by cochlear vibrations. International Journal of Audiology, 47(12), 761-769.

Franke, E. K. (1956). Response of the Human Skull to Mechanical Vibrations. Journal of the Acoustical Society of America, 28(6), 1277-1284.

Hamed, E., Jasiuk, I., Yoo, A., Lee, Y., \& Liszka, T. (2012). Multi-scale modelling of elastic moduli of trabecular bone. Journal of The Royal Society Interface, rsif20110814.

Håkansson, B., Brandt, A., Carlsson, P., \& Tjellström, A. (1994). Resonance frequencies of the human skull in vivo. The Journal of the Acoustical Society of America, 95(3), 1474-1481

Håkansson, B., Carlsson, P., \& Tjellström, A. (1986). The mechanical point impedance of the human head, with and without skin penetration. The Journal of the Acoustical Society of America, 80(4), 1065-1075. 
Håkansson, B., Eeg-Olofsson, M., Reinfeldt, S., Stenfelt, S., \& Granström, G. (2008). Percutaneous versus transcutaneous bone conduction implant system: a feasibility study on a cadaver head. Otology \& Neurotology, 29(8), 1132-1139.

Jaasma, M. J., Bayraktar, H. H., Niebur, G. L., \& Keaveny, T. M. (2002). Biomechanical effects of intraspecimen variations in tissue modulus for trabecular bone. Journal of Biomechanics, 35(2), 237-246.

Ji, S., Ghadyani, H., Bolander, R. P., Beckwith, J. G., Ford, J. C., McAllister, T. W., ... \& Raman, R. (2014). Parametric comparisons of intracranial mechanical responses from three validated finite element models of the human head. Annals of Biomedical Engineering, 42(1), 11-24.

Keaveny, T. M., Pinilla, T. P., Crawford, R. P., Kopperdahl, D. L., \& Lou, A. (1997). Systematic and random errors in compression testing of trabecular bone. Journal of Orthopaedic Research, 15(1), 101-110.

Khalil, T. B., Viano, D. C., \& Smith, D. L. (1979). Experimental analysis of the vibrational characteristics of the human skull. Journal of Sound and Vibration, 63(3), 351-376.

Kim, N., Steele, C. R., \& Puria, S. (2013). Superior-semicircular-canal dehiscence: effects of location, shape, and size on sound conduction. Hearing Research, 301, 72-84.

Kim, N., Chang, Y., \& Stenfelt, S. (2014). A three-dimensional finite-element model of a human dry skull for bone-conduction hearing. BioMed Research International, vol. 2014, 9 pages.

Kleiven, S., \& Hardy, W. N. (2002). Correlation of an FE model of the human head with local brain motion: Consequences for injury prediction. Stapp Car Crash Journal, 46, 123-144.

Lee, J. S., (1980). Digital image enhancement and noise filtering by use of local statistics. IEEE transactions on pattern analysis and machine intelligence, (2), 165168.

Levin, E., Muravchick, S., \& Gold, M. I. (1981). Density of normal human cerebrospinal fluid and tetracaine solutions. Anesthesia and Analgesia, 60(11), 814-817.

Lundgren, H. (2011). Bone conduction transducers and output variability. Chalmers University of Technology, Report No. EX042/2010, 15-18.

Luo, Y., Li, Z., \& Chen, H. (2012). Finite-element study of cerebrospinal fluid in mitigating closed head injuries. Proceedings of the Institution of Mechanical Engineers, Part H: Journal of Engineering in Medicine, 226(7), 499-509.

Mattingly, J. K., Greene, N. T., Jenkins, H. A., Tollin, D. J., Easter, J. R., \& Cass, S. P. (2015). Effects of skin thickness on cochlear input signal using transcutaneous bone conduction implants. Otology \& neurotology: official publication of the American Otological Society, American Neurotology Society [and] European Academy of Otology and Neurotology, 36(8), 1403.

Motherway, J. A., Verschueren, P., Van der Perre, G., Vander Sloten, J., \& Gilchrist, M. D. (2009). The mechanical properties of cranial bone: the effect of loading rate and cranial sampling position. Journal of Biomechanics, 42(13), 2129-2135. 
Purcell, D. W., Kunov, H., \& Cleghorn, W. (2003). Estimating bone conduction transfer functions using otoacoustic emissions. The Journal of the Acoustical Society of America, 114(2), 907-918.

Reddy, J. N. (1993). An introduction to the finite element method. New York: McGrawHill. pp 3-17.

Reinfeldt, S., Håkansson, B., Taghavi, H., \& Eeg-Olofsson, M. (2015). New developments in bone-conduction hearing implants: a review. Medical Devices (Auckland, NZ), 8, 79-93.

Reinfeldt, S., Stenfelt, S., \& Håkansson, B. (2013). Estimation of bone conduction skull transmission by hearing thresholds and ear-canal sound pressure. Hearing Research, 299, 19-28.

Rigato, C., Reinfeldt, S., Håkansson, B., Jansson, K. J. F., Renvall, E., \& Eeg-Olofsson, M. (2018). Direct bone conduction stimulation: ipsilateral effect of different transducer attachments in active transcutaneous devices. Hearing Research, 361, 103112 ,

Sahoo, D., Deck, C., \& Willinger, R. (2014). Development and validation of an advanced anisotropic visco-hyperelastic human brain FE model. Journal of the Mechanical Behavior of Biomedical Materials, 33, 24-42.

Sahoo, D., Deck, C., Yoganandan, N., \& Willinger, R. (2013). Anisotropic composite human skull model and skull fracture validation against temporo-parietal skull fracture. Journal of the Mechanical Behavior of Biomedical Materials, 28, 340353.

Sakellarios, A. I., Tachos, N. S., Rigas, G., Bibas, T., Ni, G., Böhnke, F., \& Fotiadis, D. I. (2017). A validated methodology for the 3D reconstruction of cochlea geometries using human microCT images. Measurement Science and Technology, 28(5), 054001 .

Stalnaker, R. L., Fogle, J. L., \& McElhaney, J. H. (1971). Driving point impedance characteristics of the head. Journal of Biomechanics, 4(2), 127-139.

Steele, C. R., Baker, G. J., Tolomeo, J. A., Zetes-Tolometo, D. E. (2000). Cochlear Mechanics. In The Biomedical Engineering Handbook: Second Edition. Ed. Joseph D. Bronzino. Boca Raton: CRC Press LLC, 63, 1-15.

Stenfelt, S. (2011). Acoustic and physiologic aspects of bone conduction hearing. Advances in Oto-Rhino-Laryngology 71, 10-21.

Stenfelt, S. (2012). Transcranial attenuation of bone-conducted sound when stimulation is at the mastoid and at the bone conduction hearing aid position. Otology \& Neurotology, 33(2), 105-114.

Stenfelt, S. (2013). Bone conduction and the middle ear. In Springer Handbook of Auditory Research: The Middle Ear: Science, Otosurgery, and Technology (). Ed. Puria S., Fay R., Popper A., Springer, New York. pp. 135-169

Stenfelt, S. (2015). Inner ear contribution to bone conduction hearing in the human. Hearing Research, 329, 41-51.

Stenfelt, S., \& Goode, R. L. (2005a). Bone-conducted sound: physiological and clinical aspects. Otology \& Neurotology, 26(6), 1245-1261. 
Stenfelt, S., \& Goode, R. L. (2005b). Transmission properties of bone conducted sound: measurements in cadaver heads. The Journal of the Acoustical Society of America, 118(4), 2373-2391.

Stenfelt, S., Håkansson, B., \& Tjellström, A. (2000). Vibration characteristics of bone conducted sound in vitro. The Journal of the Acoustical Society of America, 107(1), 422-431.

Stenfelt, S., \& Reinfeldt, S. (2007). A model of the occlusion effect with bone-conducted stimulation. International Journal of Audiology, 46(10), 595-608.

Stenfelt, S., Wild, T., Hato, N., \& Goode, R. L. (2003). Factors contributing to bone conduction: The outer ear. The Journal of the Acoustical Society of America, 113(2), 902-913.

Stenfelt, S., \& Zeitooni, M. (2013). Binaural hearing ability with mastoid applied bilateral bone conduction stimulation in normal hearing subjects. The Journal of the Acoustical Society of America, 134(1), 481-493.

Taschke, H., \& Hudde, H. (2006). A finite element model of the human head for auditory bone conduction simulation. ORL, 68(6), 319-323.

Tjellström, A., \& Håkansson, B. (1995). The bone-anchored hearing aid. Design principles, indications, and long-term clinical results. Otolaryngologic Clinics of North America, 28(1), 53-72.

Tondorf, J. (1966). Bone conduction studies in experimental animals. Acta Otolaryngologica, 132(suppl 213), 7-9.

Yang, J., Xu, W., \& Otte, D. (2008). Brain injury biomechanics in real world vehicle accident using mathematical models. Chinese Journal of Mechanical Engineering (English Edition), 21(4), 81-86.

Von Békésy, G. (1932). Zur Theorie des Hörens bei der Schallaufnahme durch Knochenleitung. Annalen Der Physik, 13:111-36.

Von Békésy, G. (1948). Vibration of the head in a sound field and its role in hearing by bone conduction. The Journal of the Acoustical Society of America, 20(6), 749760.

Von Békésy G. (1951). The mechanical properties of the ear. In Handbook of experimental psychology. Ed. Stevens S. S., Wiley, New York, pp 1075-1115.

Von Békésy, G. (1960). Experiments in Hearing. Acoustical Society of America, New York: Mcgraw Hill. 


\section{Papers}

The papers associated with this thesis have been removed for copyright reasons. For more details about these see:

http://urn.kb.se/resolve?urn=urn:nbn:se:liu:diva-145666 